\title{
AMOR E FINITUDE: UM DIÁLOGO ENTRE AGOSTINHO DE HIPONA E MAX SCHELER
}

\author{
Love and Finitude: A Dialogue Between Augustine of Hippo and Max Scheler \\ Amor y Finitud: Un Diálogo entre Agustín de Hipona y Max Scheler
}

Daniel Rodrigues Ramos

\begin{abstract}
Resumo: Priorizando como fio condutor a relação entre amor e finitude, a discussão estabelece um constante diálogo entre o pensamento filosófico-teológico de Agostinho e a fenomenologia de Scheler. Primeiramente, esclarece-se o horizonte a partir do qual a fenomenologia de Scheler visualiza o pensamento agostiniano ao considerá-lo sob a ótica da estrutura vivencial e fundamental do viver cristão. Evidenciando a ideia de ordo amoris, mostra-se a correspondência desta estrutura à reviravolta do amor cristão, assinalada por Scheler como a emergência da compreensão de um Deus amante. Para tanto, em seguida, discutem-se traços da hermenêutica agostiniana da vida cristã, até revelar a caritas como sendo o amor que responde pela intencionalidade ordenadora da estrutura da existência humana no seu todo segundo o seu dinamismo essencial. Sob o ponto de vista desta função central da caridade, conclui-se indicando a necessidade de considerar a interdependência entre viver e morrer, para melhor compreender o sentido da estruturação da existência humana a partir da ideia de amor ordenado. Palavras-chave: fenomenologia, afetos, ordo amoris, caridade.
\end{abstract}

\begin{abstract}
Prioritizing the guiding thread of the relationship between love and finitude, the discussion establishes a constant dialogue between Augustine's philosophical-theological thinking and Scheler's phenomenology. Firstly, it clears the horizon in which Scheler's phenomenology visualizes the Augustinian thought considered from the perspective of the experiential and fundamental structure of Christian living. Demonstrating the idea of ordo amoris, the harmony of this structure is shown in the change of the concept of Christian love, signaled by Scheler as the emergence of the understanding of a loving God. In order to do so, the traits of the Augustinian hermeneutics of the Christian life are discussed, until it reveals caritas as being the love that answers the intentionality of the structure of human existence as a whole according to its essential dynamism. From the point of view of this central function of charity, it concludes by indicating the need to consider the interdependence between living and dying, in order to better understand the sense of the structuring of human existence from the idea of ordered love.
\end{abstract}

Keywords: phenomenology, affections, ordo amoris, charity.

Resumen: Priorizando como hilo conductor la relación entre amor y finitud, la discusión establece un constante diálogo entre el pensamiento filosófico-teológico de Agustín y la fenomenología de Scheler. Primero, se aclara el horizonte a partir del cual la fenomenología de Scheler visualiza el pensamiento agustiniano al considerarlo bajo la óptica de la estructura vivencial y fundamental del vivir cristiano. Evidenciando la idea de ordo amoris, se muestra la correspondencia de esta estructura a la revolución del amor cristiano, señalada por Scheler como la emergencia de la comprensión de un Dios amante. Para ello, a continuación, se discuten rasgos de la hermenéutica agustiniana de la vida cristiana, hasta revelar la caritas como el amor que responde por la intencionalidad ordenadora de la estructura de la existencia humana en su totalidad según su dinamismo esencial. Desde el punto de vista de esta función central de la caridad, se concluye indicando la necesidad de considerar la interdependencia entre vivir y morir, para comprender mejor el sentido de la estructuración de la existencia humana a partir de la idea de amor ordenado

Palabras-Clave: fenomenología, afectos, ordo amoris, caridad.

\section{"Grava-me, como um selo em teu coração como um selo em teu braço, pois o amor é forte, é como a morte!"} (Cântico dos Cânticos 8, 6)

Mediada pela questão do sentido do amor e da transitoriedade da vida, a presente discussão é a tentativa de colocar em diálogo dois pensadores, ao mesmo tempo, unidos e separados por uma única tradição. Unidos porque ambos pertencem ao dinamismo vital da mesma história espiritual do Ocidente, iniciada pelos gregos e em consumação nos tempos da técnica e da ciência. Trata-se da história da pergunta radical pelo ser, sobretudo, mediante o questionamento da estrutura fundamental da existência do homem, nas tramas de sua relação consigo mesmo, com o outro, com o mundo e com o divino - questionamento percorrido na busca do sentido de ser e não ser, de realizar ou debilitar estas relações. De outro lado, nitidamente separados não somente por causa do hiato cronológico que, para um observador externo com sua consideração objetiva dos fatos históricos, afasta tais pensadores e os tornam estranhos um ao outro. Antes, os pensadores se distanciam porque tal história, para continuar sua marcha e manter unidos aqueles que a pensaram no seu princípio, desenvolve-se de época em época, figurando concreções radicalmente diversas do espírito, cuja regra básica deste desenvolvimento é ter 
quer instaurar rupturas com o passado, interpondo cisões e fraturas no percurso do desenvolvimento da história. Contudo, este é o modo pelo qual, em novo horizonte de pensamento e contexto de questões, os homens se põem a trilhar o caminho que é aquela história mesma e seu princípio é retomado, seja na perspectiva de revigorar como de promover o esquecimento de seu ponto de partida.

Assim, para o primeiro pensador envolvido no diálogo, Agostinho de Hipona, o âmbito espiritual da pergunta motora desta história é o Cristianismo, em um momento de inigualável vitalidade do pensamento e mística cristã, em que era necessário não somente esclarecer os seus conteúdos doutrinários e defendê-los de distorções, mas, mediante isto, veio à fala e em conceitos a evidência do modo de ser da existência cristã dada pela compreensão da fé. Nesta perspectiva, a vida e a obra de Agostinho, então, é o lugar em que a experiência constituinte da existência cristã e configuradora do mundo vivido sob os orientamentos da fé emerge em conceitos filosóficos e teológicos ${ }^{1}$. Por sua vez, para Max Scheler, o segundo pensador, o ambiente é a crise do espírito, em um tempo que tinha se obscurecido, já há alguns séculos, a compreensão da fé cristã sobre a vida e a morte mediante a substituição da experiência cristã pela estrutura vivencial do homem moderno e burguês ${ }^{2}$. Mas não apenas isto, pois é igualmente a época na qual entra em colapso e de forma violenta a ideia que o homem pode ser determinado pela posse do lógos, da ratio e da mens en-

1 Como se esclarecerá, esta é a posição assumida por Scheler (cfr. M. Scheler, Liebe und Erkenntnis, in Schriften zur Soziologie und Weltanchauunslehre, Gesammelte Werke (de agora em diante, GW) 6, Bonn: Bouvier, 2008, p.87-88; tr.esp. Amor y conocimento, in Amor y conocimento, Madrid: Palavra, 2010, p. 30-31). Outras perspectivas de considerações sobre a importância da vida e obra de Agostinho para a formação e destinação da história e cultura ocidental surgiram nas primeiras décadas do século XX, transformando o modo de impostar a problemática do sentido da obra de Agostinho e sua relação com a cultura greco-helênica. Uma brevíssima caracterização destas tendências de aproximação à filosofia e teologia agostiniana se encontra em M. Heidegger, Augustinus und der Neuplatonismus, in Phänomenologie des religiösen Lebens, Frankfurt a.M.: Vittorio Klostermann, 2011, p. 159-73; tr. por.; Agostinho e Neoplatonismo, in Fenomenologia da vida religiosa, Petrópolis: Vozes, Bragança Paulista: São Franscisco, 2010, p.143-55. Esta sintética apresentação de Heidegger das compreensões de Ernst Troeltsch, de Adolf von Harnack e de Wilhelm Dilthey, porém, tem em vista mostrar que compreensões objetivantes da história não acessam o problema central da interpretação da obra de Agostinho, que seria a explicitação fenomenológica da experiência do viver fático. Somente nas bases de uma ontologia da vida fática, segundo Heidegger, se poderia colocar de modo originário o fenômeno da historicidade e do sentido do acontecimento histórico e, assim, avaliar a importância de Agostinho no desenvolvimento da história ocidental desde o fluxo de experiências que a vida faz de si mesma e a partir de si mesma. Ora, é nesta perspectiva que Heidegger (Augustinus und der Neuplatonismus, p. 159; tr. por.; p. 143) faz uma nota sobre a posição de Scheler, deixando-a sem maiores esclarecimentos: "O que Scheler faz hoje é somente uma recepção secundária deste círculo de ideias [do agostiniasmo], enfeitado de fenomenologia". Nisto se revela uma diferença na compreensão do método, objeto e tendência fundamental da fenomenologia entre estes dois pensadores, embora concordem no seguinte, conforme a expressão de Scheler (Liebe und Erkenntnis, p.87; tr. esp.; p. 30): a experiência cristã que emerge conceitualmente na primitiva constituição da dogmática cristã, em oposição ao que habitualmente se expõe nas considerações historiográficas, não é simplesmente "uma filosofia grega com ornamentos cristãos, senão um sistema de pensamento surgido da raiz e essência da vivência cristã fundamental, mediante a consideração pensante de si mesma (selbstdenkerische Betrachtung) e sondagem (Erfoschung) de mundo".

2 Cfr. M. Scheler, Tod und Forteleben, in Schriften aus dem Nachlaß, Band I, GW 10, Bonn: Bouvier, 2000, p. 28-30; tr. por.; Morte e sobrevivência, Lisboa: Edições 70, 2017, p. 36-38. quanto faculdades superiores dispostas ao arbítrio humano. É a crise da certeza e segurança absolutas, segundo a mentalidade moderna, na capacidade de fazer bom uso do poder humano de julgar - como diria Descartes, de bem aplicar o bon sens, igualmente distribuído a todos os homens ${ }^{3}$-, seja com fins cognoscitivos, como também éticos, de modo a alcançar mediante tal poder a perfeição do espírito. Deste modo, é o tempo que não pode mais somente chegar à ideia do sentido do viver e morrer humano, assumindo às cegas o discurso lógico-científico das ciências naturais e da psicologia, o que não significa rejeitar as suas conclusões.

Para o pensamento, porém, esta crise do espírito é instigadora, pois faz urgir a necessidade de perguntar de novo e essencialmente quem é o homem e determinar sua posição originária na totalidade do ser, a partir da intenção fundamental e ordenadora dos fins que destina e configura epocalmente a estrutura da existência humana. E, com isto, é ocasião para voltar o olhar para o longo passado desta história do pensamento e estabelecer um diálogo tanto com a tradição da antiguidade clássica como a medieval, em vista de elaborar um conceito essencial de homem, de compreensão de sua posição no cosmos, tal como a proposta de Scheler ${ }^{4}$. Este questionamento é levado a cabo, principalmente, em tempos críticos da história, isto é, quando o que caracteriza essencialmente o espírito do homem se obscurece e o viver humano protende a desfalecer-se na aridez destes tempos. O mesmo questionamento foi outrora, entretanto, em tempos de florescimento de uma nova possibilidade, favorecida pelo cristianismo, de compreender a essência e o lugar do homem, foi perpassado pela tematização do sentido da finitude humana e de sua assunção segundo o amor, tendo em Agostinho um mestre e necessário interlocutor. Todavia, não em razão do fato que a ordem do coração é fonte de amenidades e agradáveis sentimentalidades. Por certo, porque, para ambos os pensadores, o "sentimento" do amor aparece, sobretudo, como uma intentio que, ordenando a existência desde sua raiz para seus fins mais próprios, impede que a existência, dizendo com Agostinho, morra de inanição no deserto da ausência do sentido originário do viver (e do morrer), conduzindo-a para a condição e pátria em que ela repousa e se sacia ${ }^{5}$.

Como, porém, é possível um diálogo sobre o sentido do viver e do morrer sob a ótica do amor, sobretudo, quando os interlocutores pertencem a âmbitos espirituais tão divergentes, de tal modo que os contextos de questões e paisagens existenciais em que a existência humana percorre o caminho de sua realização histórico-espiritual são extremamente diversos? A pergunta pressupõe a elaboração de uma

3 Cfr. R. Descartes, Discours de la méthode, Paris: GF Flammarion, s.d., p. 29-30.

4 Para esta perspectiva filosófica, dê-se especial atenção às palavras introdutórias de M. Scheler, Die Stellung des Mensches in Kosmos, in Späte Schriften, GW 9, Bonn: Bouvier, 2008, p. 11-12; tr. por. A posição do homem no cosmos, Rio de Janeiro: Forense Universitária, 2003, p. 5-7.

5 Cfr. Aurelius Augustinus, In epistolam Ioannis ad Parthos Tractatus decem, VII, 1; tr. it.; Commento alla lettera du San Giovanni, disponível em www.augustinus.it, acesso em 29/10/2017. 
discussão que aqui não pode ser (re)feita. Em todo caso, é possível alegar apenas algumas indicações. A primeira delas é recordar que o diálogo, enquanto experiência de pensamento, não é nenhum espaço nem recurso metodológico, cujo fim seja o comum acordo, o lugar de aplanamento das divergências e contraposições, de determinação de influências, modos de recepção, consonâncias e dissonâncias e, enfim, de reelaborações de antigas teorias. Antes, o diálogo é lugar de um confronto. Na medida em que cada posição de um pensador é essencial, ela não é não é contra nem a favor de uma posição anterior ou pertencente ao porvir na história da verdade. É somente sua posição singular ${ }^{6}$. Por isto, o diálogo de pensamento é o caminho que cada um dos participantes caminha solitariamente - mas sempre no embate com outros que lhe antecederam com aqueles que lhe haverão de suceder-, cada vez mais intensamente, para a raiz desconhecida da própria questão, aproximando-se do fundamento da verdade histórica do próprio pensamento, conformadora do próprio tempo. Mas nesta verdade, não obstante as diferenças e concreções específicas, toca-se o fundo e o profundo do acontecer histórico, porque nele se desvela a experiência da existência na sua crueza e na sua universalidade, de tal modo que a singularidade de sua busca de questionamento é a o lugar de encontro e descoberta da unicidade histórica do ser e da verdade.

Depois, em segundo lugar, um diálogo de tal sorte não é possível em torno das expressões específicas do viver e o do morrer, mas sim no princípio em torno daquilo que constitui a vida e a morte na sua mais pura faticidade, para usar uma expressão bem cara à fenomenologia do sentido do ser de Heidegger. É no perfazer da existência mesma, independente dos conceitos filosóficas e teológicos utilizados para liberá-la numa postura compreensiva sobre o sentido do viver e do morrer, que todos os pensadores podem se encontrar em comunhão e, ao mesmo tempo, em contraposição. A este ponto, a história é o espaço da convergência no mesmo que é sempre uma convocação ao pensar ao longo do viver e morrer de todo homem, bem como da divergência no conteúdo específico da posição de cada pensador, pois o encontro e a descoberta da unicidade da verdade e do ser da existência humana nunca se dão no espaço abstrato e vazio das impostações teorético-cognoscitivas, mas sim no limite das finitudes históricas e das figuras das concreções espirituais. Na conjunção destas duas pressuposições, porém, a história golpeia e aflige todo e qualquer homem, independente de tempo, espaço e época em que se situam aqueles que nela sempre dialogam, mesmo quando sem saber que dialogam, o que ou porque dialogam num confronto contínuo:

A história nos afeta e nós mesmos a somos: e justamente por não vermos isso, quando cremos possuir e dominar uma compreensão objetiva da história até hoje nunca alcança-

\footnotetext{
6 Cfr. M. Heidegger, Besinnung, Frankfurt a.M.: Vittorio Klostermann, 1997; p. 74-75; tr. por.; Meditação, Petrópolis: Vozes, 2010, p. 73.
}

da, justamente porque pensamos isso e, nessa opinião, continuamos e imaginando e construindo presumivelmente cultura, filosofia e sistemas, de tempos em tempos, a história nos golpeia, com maior força, a nós mesmos. ${ }^{7}$

É no embate com uma única questão - talvez, a questão quem somos nós?, colocada por nós mesmos e para (aclarar o sentido de sermos) nós mesmos, seja na guarda do Deus cristão, seja historialmente longe de seus olhos - que a história golpeia todos os homens e o diálogo acontece. Acontece, porém, sempre em perspectivas e horizontes epocais, suplantando abismos entre estes. Por isto, antes de fazer a descrição pontual de alguns aspectos do diálogo entre os dois pensadores é necessário apontar algumas perspectivas em que a fenomenologia de Scheler encontra e se confronta com o pensamento filosófico-teológico de Agostinho. Estas perspectivas são discutidas na direção de desentranhar o horizonte do diálogo, aberto a partir da visualização da fenomenologia de Scheler e que permite a esta uma específica elaboração da mesma questão. As linhas a seguir, porém, não traçam um inventário exaustivo e definitivo das direções pelas quais o primeiro realiza uma análise e interpretação fenomenológicas da obra de Agostinho. Pelo contrário, as breves considerações abaixo são apenas um esboço demasiadamente provisório, na medida em que se detém neste confronto, visualizando-o pela estreita perspectiva da discussão do fenômeno do amor e, ainda, a partir de um número bastante restrito de escritos, aqueles que versam explicitamente sobre esta questão. É ainda por se questionar se o decisivo para o diálogo e confronto, vistos a partir da fenomenologia de Scheler, não se revela não tanto no que encontra formalmente expresso sobre o pensamento de Agostinho, mas muito mais na tendência fundamental que opera no interno desta fenomenologia e, por isso, não visível apenas na forma explícita de posicionamentos hermenêuticos. Ademais, a provisoriedade na discussão encontra-se no lado mesmo dos escritos escolhidos, visto que se trata de um propósito de elaborar uma sistemática discussão do fenômeno do amor não foi plenamente realizado, e especial, em referência às suas conexões e relação essencial com o fenômeno do conhecimento. Nesta direção de abordagem da questão, o ensaio publicado pela primeira vez em 1915, Liebe und Erkenntnis, é paradigmático ${ }^{8}$. Este é tomado como ponto de partida. Somente em seguida, despois de liberar este horizonte como sendo o espaço de interpretação do viver humano a partir da ideia do ordo amoris ou do amor ordenado, poder-se-á retornar a Agostinho, para no seu pensamento encontrar traços desta hermenêutica.

$7 \quad$ M Heidegger, Augustinus und der Neuplatonismus, p. 173; tr. por., p. 155.

8 O escrito é reeditado em 1916 e, por fim, em 1923 é recolhido como um capítulo da obra entitulado Moralia, tal como aparece no volume supracitado das obras completas de Scheler. Contudo, o escrito deve ser tomado como o esboço da elaboração muito mais ampla da questão da relação entre amor e conhecimento. No prefácio de 1920 de Vom Ewigen im Menschen, Scheler anuncia o propósito de realizar uma explicitação "puramente objetiva e sistemática da relação da relação entre amor e o conhecimento", que certamente conecta-se com seu propósito, anteriormente explicado no mesmo prefácio, como será aludido abaixo, de liberar o núcleo do agostianismo mediante a elaboração de uma "teologia da experiência essencial do divino”. O projeto, porém, não foi realizado antes de sua morte. Cfr. M. Scheler, Vom Ewigen im Menschen, GW 5, Bonn: Bouvier, 2007, p. 8-9; trd. por., Do eterno no homem, Petrópolis: Vozes, Bragança Paulista: 2015, p. 9-10. 
Por fim, algumas palavras são ditas a respeito da conexão entre amor e finitude, a fim de explicitar o eixo implícito da presente discussão e, com isto, concluí-la.

\section{O horizonte do confronto da fenomenologia de Scheler com o pensamento agostiniano a partir do fenômeno do amor}

Em seu conjunto, o ensaio supracitado, Liebe und Erkenntnis, apresentada, em traços largos, tipos historicamente universais em que a relação entre o amor e conhecimento foi apreendida ao longo da história, elaborando diferentes soluções para o problema de determinar como se dá a interdependência dos dois fenômenos em questão em três grandes tendências ou tradições: a hindu, a grega e, por último, a cristã. Grosso modo, o escrito combate a compreensão que mantém as duas primeiras soluções estreitamente unidas: a impostação do problema, essencialmente intelectualista, que coloca o amor em posição de dependência de outro fenômeno de maior dignidade, o conhecimento, na medida em que, numa perspectiva teleológica, o último é a meta final a que se encaminha o pensamento de maneira crescente ou numa constante progressão na intensificação do próprio conhecer. Na solução do problema, portanto, se estabelece uma via, em cujo percurso até o seu fim - o método - o resultante é a tomada de posse ou assenhoreamento do ser do conhecimento por ele mesmo, em virtude do fato que também, ao longo da travessia da via, atravessa-se igualmente o real em direções cada vez mais densas ou plenas de ser'. É, por exemplo, a clássica pressuposição da dialética grega, segunda a qual o conhecimento se dá, verdadeiramente, na necessária passagem da mera aparência para a essência

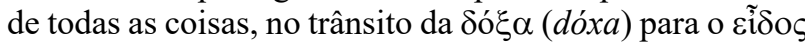
(eidos) e, em outras variantes, do sensível para o eidético, do acidental para o substancial; enfim, do não ser, $\mu$ ஸे öv,

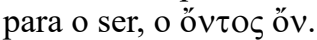

Em consequência desta compreensão, o amor torna-se refém do progresso cognoscitivo e, ao mesmo tempo, já que ele funciona apenas na forma de um incitamento, seja ao modo de um impulso criador, seja na forma de desejo ou de carência. Mostra-se apenas como trânsito. Por isto, o amor é um dinamismo, porém, que não chega ao seu fim. A meta é de propriedade do conhecimento. Assim, o amor é desejo sempre carente, pois não se apodera

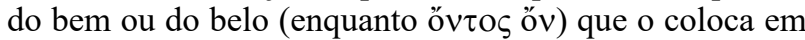
movimento e, por consequência, apenas impele o conhecimento: o amor mesmo não conhece, nem que seja em um modo bastante particular. Para o conhecer, portanto, o amor é a via ou o método, porém, a ser descartado quando o primeiro salta para a posse de seu fim último, já que é percurso que jamais pode se desembocar nesta meta final ou, de outro modo, não pode unir-se ao "objeto" de seu desejo. Nisto, o amor não é consumar-se ou plenificar-se na consumação do fim. Deste modo, na medida em que a posse do "objeto" amado pertenceria exclusivamente ao conhecimento, o amor permanece sempre no meio e como meio, pois é só envio enquanto o motor da via que conduz ao conhecimento. É por graças da compreensão intelectualista, então, que a sina do amor é ter que permanecer entre a pobreza do não ter o que se ama e a riqueza da plenitude da fruição do amado.

Em síntese, sob o fundo desta concepção da relação amor-conhecimento,

9 Cfr. M. Scheler, Liebe und Erkenntnis, 83-84; tr. esp., p. 22-23.
Todos os pensadores, poetas, moralistas antigos estão de acordo no que concerne ao fato de que o amor é uma aspiração, uma tendência do "baixo" para o "alto", do "menos plenificado" ao "mais plenificado", do "não conformado" ao "conformado", do " $\mu \grave{\eta}$ ő $v "$, da "aparência" à "essência", do "não saber" para o saber", um "médio entre ter e não ter", como diz Platão no Banquete. Assim, todas as relações de amor entre os homens, os casais, os amigos etc., decompõe-se em um "amante" e um "amado", sendo que o amado sempre se apresenta nestas relações como o mais nobre, a parte mais plena, e ao mesmo tempo o modelo para o Ser, o querer e a ação do amante. ${ }^{10}$

Todavia, o amado se constitui como modelo de ser, agir e querer do amante não apenas só porque, enquanto őv $\tau$ os ő $v$, configura-se como a ideia que constitui o fim último do conhecimento, mas principalmente porque o por ser conhecido enquanto princípio e meta derradeira do conhecer, na sua máxima acepção e realidade, tem o caráter de divino, de uma divindade. No dizer de Aristóteles, o fim último do conhecimento tem o caráter de um @eíov, ao qual se dirige a $\dot{\varepsilon} \pi 1 \sigma \tau \eta ́ \mu \eta$ (espistéme) das causas primeiras, em especial, daquela que é a causa imutável, na medida em que esta ciência enquanto $\pi \rho \omega ́ \tau \eta ~ \phi ı \lambda o \sigma o \phi i ́ \alpha$ (proté philosophía) deve considerar e corresponder ao modo mais perfeito ou pleno do ser se mostrar enquanto tal ( $\tau$ ò obv $\tilde{\eta}$ ǒv $)^{11}$. Inserindo a divindade dentro desta estrutura onto-teológica da metafísica, algo de essencial do amor será desvelado, a saber, a ideia de que o amor é justamente este movimento ascendente, em direção à plenitude do ser, pois tudo que é se encontra atraído por este divino que, como motor imóvel, coloca cada ente em movimento em direção para este bem mais elevado. Todo o universo, então, é concebido como uma cadeia, em que os elementos estão encadeados pelos laços do amor enquanto princípio dinâmico e articulador que impele, num movimento ascensional, dos entes em menor dignidade de ser, passando pelo homem, até as alturas mais elevadas do ser mesmo ${ }^{12}$, no modo de uma inteligência divina que tudo "move como um amado"13.

Scheler não deixará de enfatizar, em termos de manifestação e da apreensão de valores, a positividade deste movimento, assumindo-o como o traço fundamental do amor: "o amor é um movimento, o qual vai do valor mais baixo ao valor mais alto e no qual, em cada caso, relampeja o valor mais alto de um objeto ou pessoa"14. Até mesmo no fenômeno oposto, o ódio, o movimento não é negado como aspecto essencial, mas somente estabelecido como dinamismo em direção contrária: um tender de valores mais altos para mais baixo. Contudo, em virtude desse movimento, o amor precisa de um ponto de chegada, onde possam repousar a agitação e a inquietude, nascidas

10 M. Scheler, Das Ressentiment im Aufbau der Moralen, in Vom Umsturz der Werte, GW 3, Bonn: Bouvier, 2007, p. 71; tr. por., O ressentimento na construção das morais, in Da reviravolta dos valores, Petrópolis: Vozes, Bragança Paulista: Universitária São Francisco, 2012, p. 90. Tradução modificada e corrigida.

11 Cfr. Metafísica 1003a 20-25; 1026a 15-30; tr. por. Aristóteles, Metafísica, São Paulo: Loyola, 2002, p. 130-131; 272-73.

12 Cfr. M. Scheler, Das Ressentiment im Aufbau der Moralen, p. 72; tr. por., p. 91

13 Metafísica 1003 3-4; tr. por., p. 563

14 M. Scheler, Wesen und Formen der Sympathie, GW 7, Bonn: Bouvier, 2009, p. p. 155; tr. esp., Esencia y formas de la simpatía, Buenos Aires: Losada, 1950, p. 212. 
do anelo de encontrar plenamente realizado o valor que no amado foi antevisto e, então, preencher o anseio de com ele unir-se na perfeição de seu ser e valor. O amor é satisfação ascendente ou, a menos, um esforço contínuo para elevar-se a esta satisfação, o qual se arremata numa crescente serenidade e plenitude, porém, somente na medida em que este movimento, de um lado, revele-se como progressiva manifestação do valor no objeto ou pessoa amada e, de outro, como (incremento de) visualização por parte do amante desta mudança axiológica no amado enquanto um acrescer-em-mais-valor ${ }^{15}$. O amor, então, não se aquieta enquanto não ver plenificado aquilo que, na sua clarividência, já anteviu e conheceu como possibilidade de ser mais própria do amado.

Este movimento vale para a relação amorosa com qualquer objeto ou pessoa. Somente uma esfera absoluta e divina, entretanto, estaria em condições de dar preenchimento à tendência interna deste movimento, realizando os auspícios mais originários, o que, no final das contas, é terminar como conhecimento mais radical possível. Todavia, isto não significa que tal esfera em que se dá a plena satisfação seja de acesso exclusivo ao conhecer e que, por isto, o amor tenha que ser impedido de experimentá-la. As coisas devem ser compreendidas em outra direção de estabelecer a interdependência, de modo tal o amor não seja somente o pressuposto para o movimento do conhecer, isto é, seja exigido de antemão o amor ao conhecimento. De fato, a experiência cotidiana já ensina: conhece-se melhor e mais perfeitamente, pois, aquilo que primeiro se ama. Ao mesmo tempo, porém, é necessário que o conhecer sucumba ao amor, tornando-se conhecimento no amor. Com efeito, o conhecimento que é a intelecção rigorosamente evidente de uma esfera do absoluto, para além e acima da intuição de essências ainda referidas a existência casual de objetos, algo possível unicamente como filosofia ${ }^{16}$, pressupõe como condição moral prévia o amor pelo ser e valores absolutos. Este amor, aviltando toda relativização e qualquer tendência humana de centrar em si a origem das questões e pôr-se como fundamento inconcusso, é ponto de partida deste movimento ascendente rumo a um ser absoluto ${ }^{17}$ e de substância inteligível, aliás, fora da cesura entre essência e existência. Mas não só. Pressupõe também que se permaneça neste amor e no seu movimento na forma da relação espiritual e participação propriamente humana na esfera deste ser ab-soluto e na sua essência.

Seja qual for o modo desta participação - o que aqui não é possível elucidar, mas tão somente afirmar que se trata de um amar concomitante ao ser absoluto ${ }^{18}$ no ato

15 Cfr. M. Scheler, Ordo Amoris, in Schriften aus dem Nachlaß, Zur Ethik und Erkenntnislehre, GW 10, Band 1, Bonn: Bouvier, 2000, p. 359; tr. por. Ordo amoris, p. 18. Diponível em: <http.www. lusosofia.net>. Acesso em: 26 jul. 2016.

16 Cfr. M. Scheler, Vom Wesen der Philosophie und der moralischen Bedingung des philosophischen Erkennens, in Vom Ewigen im Menschen, GW 5, Bonn: Bouvier, 2007, p. 97-99; trd. por., Sobre a essência da filosofia e a condição moral do conhecimento filosófico, in Do eterno no homem, Petrópolis: Vozes, Bragança Paulista: 2015, p. $129-32$

17 Cfr. M. Scheler, Vom Wesen der Philosophie und der moralischen Bedingung des philosophischen Erkennens, p. 89-90; tr. por., 118-20.

18 Cfr. M. Scheler, Vom Wesen der Philosophie und der moralischen Bedingung des philosophischen Erkennens, p. 71-72; tr. por., 94-95. Para esta noção de correalização (Mitvollzug) dos atos espirituais enquanto modo de uma pessoa participar e conhecer a vida interior de outra pessoa e isto como modalidade de conhecimento própria do amor, cfr. M. Scheler, Der Formalismus in der Ethik und amoroso de sua própria essência -, Scheler não poderá deixar de assumir a necessidade, tal como no esquema teórico intelectualismo, de manter a ideia de uma instância espiritual suprahumana, enquanto o vértice para o qual as todas as demais esferas, humana e infra-humanas, se dirigem mediante seus exemplares no movimento do amor $e$ do conhecer. Com toda certeza, esta meta final do movimento não mais possui o caráter de um motor primeiro (embora ainda seja uma esfera de atração de todos os entes, inclusive os privados de espírito) ou, mais amplamente dizendo, não simplesmente como princípio e término do caminho crescimento e aperfeiçoamento do conhecimento $^{19}$. Antes, o ser absoluto é considerado como pessoa divina, o "amor criador e misericordioso" 20 e, assim, aquela única esfera que o bem pleno e a bondade infinita podem figurar como dom sem limites e, portanto, promover a satisfação infinita da crescente insatisfação do amor humano. Em outros termos, segundo a mentalidade medieval e tradição da mística cristã, esta esfera é aquela que torna possível a vita beata, pois esta consiste na summi

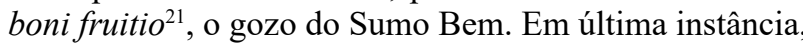
então, necessitasse-se ter em Deus, dizendo com Agostinho, tanto a verdade eterna como a beleza mais antiga, na qual o coração possa encontrar repouso no amor $e$ no conhecimento e cuja quietude não é mais do que alquilo que caracteriza a beatidude tão ansiada pelos homens: gaudium de veritate ${ }^{22}$. Nesta direção, o amor se pacifica na alegria do conhecimento da verdade, que é Deus. Em todo caso, tal como assume Scheler, na esteira deste pensador cristão, o êxito do esforço contínuo de progressão amor ocorre se ele corre para a fonte de seu movimento, para nela inserir-se e aí encontrar aquela plena felicidade que Agostinho teria já indicado como sendo a alegria $\mathrm{em}$ Deus, de Deus e por Deus ${ }^{23}$. Em síntese, a mais plena serenidade que o homem pode experimentar logra senão por graça de um bem infinito:

(...) um amor essencialmente infinito - embora enfraquecido, atado e particularizado pela organização específica de seus portadores exige um bem infinito para a sua satisfação. $\mathrm{O}$ objeto da ideia de Deus (a partir da vertente formal dos dois predicados do bem e da forma infinita do ser) em virtude do caráter essencial do amor, está subjacente à ideia de um ordo amoris. "Inquietum est cor nostrum donec resquiescet in te”. Deus, e só Deus, pode ser o vértice da construção gradativa e piramidal do

die materiale Wertethik, GW 2, Bonn: Bouvier, 2000, p. 386; tr. it., Il formalismo nell'etica e l'etica materiale dei valori, Milano: San Paolo, 1996, p. 478; Wesen und Formen der Sympathie, p. 166, 168-9, 219-20; tr. esp., p. 225, 229, 303; Die Stellung des Mensches in Kosmos, p. 39-40; tr.por., p. 45-46. Recentemente, discuti brevemente a noção em D. R. Ramos, Amor e conhecimento na fenomenologia de Max Scheler, in Aoristo: International Journal of Phenomenology, Hermeneutics and Metaphysics, 1 (2017), v. 2, Toledo, p. 168-71.

19 Cfr. M. Scheler, Liebe und Erkenntnis, 83; tr. esp., p.23.

20 M. Scheler, Vom Wesen der Philosophie und der moralischen Bedingung des philosophischen Erkennens, p. 71; tr. por., 94.

21 S. Bonaventura, Itinerario dela mente in Dio, Arezzo: La Verna, 1987, p. 14; tr. por. São Boaventura, Itinerário da mente para Deus, Vozes: Petrópolis, 2012, p. 23. O texto latino é retirado da versão italiana, que reproduz a edição crítica de Quaracchi.

22 Cfr. Aurelius Augustinus, Confessionum, X, 23, 34, disponível em www.augustinus.it, acesso em 29/10/2017; tr. por. Confissões, Petrópolis: Vozes, 2002, p. 240.

23 Cfr. Aurelius Augustinus, Confessionum, X, 22, 32; tr. por., p. 240: "Et ipsa est beata vita, gaudere ad te, de te, propter te". 
reino dos caracteres amados - ao mesmo tempo fonte e meta do todo. ${ }^{24}$

Por conseguinte, da pressuposição acima descrita decorre não só uma ordenação da totalidade do ente, encaminhada e enlaçada nas tramas do amor, dirigindo-se para um ápice como sendo o ser mais amável, melhor, absolutamente amável, mas também a necessidade de uma correta disposição da existência humana segundo o fim de suas tendências, em função de amar de modo justo cada coisa segundo seu ser e valor. Ter e remeter-se a Deus como o ser absolutamente amável implica uma ordinatio dilectio, um amor genuinamente ordenado. Dizendo com as palavras de Agostinho, é necessário dispor-se, em um modo de ser e viver sancte et juste, para ter um amor ordenado, ordinatam habet dilectio$n^{2}{ }^{25}$. E isto é: querer amar só a Deus por si mesmo (Deus propter seipsum) é também poder e ter que amar as coisas, o próprio corpo, a si mesmo e o outro apenas relativamente, ou seja, na remissão retrospectiva para origem que é Deus (propter Deum). Desta reta ordenação da existência surge, então, a hierarquização dos fins, cujo significado é o imperativo de amar toda e qualquer criatura, porém, na justa ordem segundo a dignidade de cada uma dentro de uma gradação de dileção e preferências, sempre referida àquele amor absoluto. Assim, tudo deve ser amado em Deus e em virtude de Deus e, portanto, somente será justa a fruição de e em Deus (enquanto ato e modalidade específica de amar e aderir ao amado), pois frui est enim amore inhaerere alicui rei propter seipsam, "fruir é aderir a alguma coisa por amor a ela própria"26. Por consequência, amar o que não se deve amar (por exemplo, o pecado no homem, em vez de sua pessoa por causa de Deus); ou muito amar o que deveria ser pouco amado (por exemplo, antepor os bens sensíveis aos espirituais); amar igualmente o que, necessariamente, deveria ser amado de modo diferente (estimar, numa intensidade igual, sem distinção de prioridades e preferências, os entes ou bens que deveriam ser amáveis diversamente a causa da gradação em dignidade ontológica existente entre as criaturas); bem como amar diferente aquilo que necessita ser amado igualmente (estimar em intensidade diversa, estabelecendo prioridades e preferências entre bens que deveriam ser igualmente amáveis por causa da inexistência de nenhuma variação em termos de dignidade ontoló-

24 M. Scheler, Ordo Amoris, p. 359; tr. por., p. 19.

25 Cfr. Aurelius Augustinus, De doctrina christiana libri quartor I, 27, 28, disponível em www.augustinus.it, acesso em 29/10/2017; tr. por., Santo Agostinho, A doutrina cristã: manual de exegese e formação cristã, São Paulo: Paulus, 2002, p. 66.

26 Aurelius Augustinus, De doctrina christiana libri quartor, I, 4, 4 ; tr. por., p. 44. Deste modo, a fruição é o fim adequado a certa modalidade de amor em que o homem permanece fixo junto àquilo que ama, por amá-lo em vista dele mesmo, isto é, aquilo que por si só basta ao homem para alcançar a beatidude. Por consequência todos os demais atos humanos, mesmo sendo também eles dinamizados e intencionados pelo amor com suas outras modalidades não terão o caráter de adesão aos objetos amados, mas de mediação, pois serão usados em vista de obter um bem superior; usa-se, portanto, as coisas que se deve ultrapassar em vista de reunir e encaminhar todos os afetos para aquele modo primeiro e mais perfeito de amar e para seu "objeto" de amor (cfr. nota 76). Se o fim último é a vita beata, o gáudio da aderência eterna a Deus, então, "fruir da beatitude e usar todo o resto com vista a obtê-la: tal é a regra primeira da vida cristã" (É. Gilson, Introdução aos estudos de Santo Agostinho, São Paulo: Discurso Editorial; Paulus, 2006, p. 316). Eis o princípio da ordenação do amor e, como tal, de realização dos atos humanos. No entanto, esta ordenação, como se acentua abaixo, necessita ser entendida não somente em perspectiva moral, mas também da estruturação da totalidade da vida humana, inter-relacionando e unificando as dimensões do ser do homem e, assim concretizando o seu viver segundo sua determinação essencial. gica dos entes amados), tudo isto significa desordenar o que foi, em termos ontológicos, foi gradualmente preestabelecido por Deus na criação. Uma desordem, porém, que não só desarranja o mundus como a totalidade da criação (os céus e a terra, os seres visíveis e invisíveis, como também aqueles que fazem do mundo sua morada, então, os homens $)^{27}$, indo ao contrário da hierarquização da dignidade dos bens, estabelecida no ato criador, mas que também desorganiza a existência humana no seu todo ao tomar parte neste mundo e relacionar-se com as demais criaturas que o constituem. Ora, o homem é incluído no mundo, mas, diferente da inclusão de todas as demais criaturas, esta revela que sua mundanidade é uma pertinência que se concretiza mediante a ordenação de seus afetos e segundo enorme diversidade e variações de propensões e valorações, presentes na sua alma, isto, conforme seu motus cordis, o movimento de seu coração ${ }^{28}$, o qual pode ir contra ou favor da harmonia da totalidade do criado, justamente disposta pelo ato criador. E como este ator criador é um ato de amor, no fim, aquela desordem é uma contraposição ao amor divino ou um amar humano que se movimenta em direção oposta em que o amor divino ama as criaturas: ama-se o mundo, mas não em Deus (in Deo $)^{29}$.

Certamente, um ato criador que o homem também pode continuar ao amar na mesma direção que ama Deus, na medida em que reconhece, reafirma ou reestabelece a justa ordem desta criação, já dizendo com Scheler, mediante a remissão de seus atos afetivos a cada ente conforme um específico ordo amoris, noção de sua fenomenologia que indica a estruturação intencional da existência humana segundo a "ordenação de seus atos amor e ódio"30. Necessário é, porém, que esta organização dos fins ordene a estrutura ontológica da existência segundo um modo que não só revele que o homem é, por essência, ens amans antes de ser ens cogitans ou ens volens ${ }^{31}$, isto é, concretize a essência do homem como ser espiritual, de tal modo que, também nele, tudo que é de menor valor ou inferior em dignidade (o corporal-sensitivo e o psíquico-intelectual) deve ser subordinado à dimensão da pessoa livre e espiritual que o define essencialmente. Mas se esta concretização corresponde à posição, assinalação e aos fins preestabelecidos por aquele amor criador e generoso, mostra-se que, no fim, "o ordo amoris é o cerne da ordem mundana enquanto ordem divina" ${ }^{\prime 32}$. Em concretizar-se segundo o sentido mais originário de sua essência, então, o homem também recria o mundo segundo a disposição dada pelo amor divino. Nisto, o homem estaria reconduzindo tudo para a fonte no movimento do amor em Deus e para Deus, inclusive ele mesmo, num jogo existencial de perder-se e encontrar-se que pertence às vicissitudes da história de ordenação e destinação da própria existência e de edificação de seu ethos.

A despeito desta assunção do amor como movimento que tem em Deus o fim último do conhecimento e que inclui a decisão do homem a respeito da ordenação da sua existência, as análises fenomenológica de Scheler não deixarão de denunciar sérias restrições que o modelo intelectualista do amor instaura. Primeiramente, é digna de nota é a denúncia, por assim dizer, de um enrijecimento da

27 Cfr. Aurelius Augustinus, In epistolam Ioannis ad Parthos Tractatus decem, II, 12

28 Cfr. Augustinus Hipponensis, Confessionum, IV, 14, 22; tr. por. p. 89:

29 Cfr. Aurelius Augustinus, Confessionum, IV, 12, 18; tr. por., p. 86:

30 M. Scheler, Ordo Amoris, p. 348; tr. por., p. 3.

31 Cfr. M. Scheler, Ordo Amoris, p. 356; tr. por., p. 15

32 Cfr. M. Scheler, Ordo Amoris, p. 356; tr. por., p. 15. 
divindade ${ }^{33}$. Com efeito, esta divindade que é apenas o objeto do conhecimento, essencialmente, é uma entidade paralisada, tanto porque é imóvel e não sofre nenhuma transformação, como porque é fixada com a meta que, talvez,

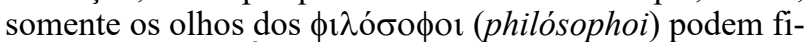
tar e contemplar. É um deus que não se movimenta, fazendo resplandecer no mundo a sua essência; unicamente o universo se movimenta a em direção a ele. E isto em razão do fato que o amor não lhe pertence, não obstante possa suscitar um amor a esta divindade enquanto um amor à

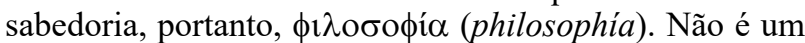
deus amante, pois o amor reside apenas no mundo, reduzido como princípio dinâmico. Essencialmente, esta é a diferença entre a concepção intelectualista grego-hindu que Scheler crê superada pela novidade da compreensão cristã. O Deus cristão é uma divindade amante e, sobremaneira, o amor mesmo.

A novidade, então, é descrita na forma de uma radical inversão do movimento ${ }^{34}$. Em que consiste esta inversão? Certamente, em primeiro lugar, significa que o movimento do amor não parte mais do mundo, mas sim do próprio Deus, dirigindo-se para toda e qualquer criatura. Então, impõe-se um movimento mais originário, que não é do inferior para o superior, do menos nobre pra o mais digno, que correspondia ao aperfeiçoamento crescente do conhecer, mas sim que assinala uma atitude superior, enquanto dignidade de ser e querer, daquele que é mais nobre ao dirigir-se e dobrar-se para o que é inferior. Agora, o movimento se inverte do ǒv para o $\mu$ ฑ̀ őv, do que é plenitude em ser para que o que é, progressivamente, menos pleno. Então, por causa desta nova direção, o amor se torna uma condescendência divina pelo que é mais pobre, pequeno, fraco e até vil, não por causa da indigência e imperfeições do amado, mas, antes, por mor da própria essência divina compreendida como amor. Por isto, "o amor cristão é uma intenção espiritual supranatural" 35 , não ato meramente sensível e nem ato exclusivamente psíquico, como pura intelecção de essências, conformando-se como um amor intelectual. É ato da difusão do espírito e emanação de Deus enquanto pessoa divina. Por assim ser, brotando espontaneamente e sem limites do mais pleno, já que, logicamente, o imperfeito não pode ser razão suficiente para ação do mais perfeito, é uma ação que cresce no seu próprio agir, por si mesmo, independente do mérito do amado, indiferente se sua resposta será a correspondência a este amor e, sobretudo, sem fazer cálculos, por exemplo, da dignidade do amado, do bem a ser provocado, se haverá dor, se o ganho será algo de prazer ou uma sensação agradável, se, no fỉm, haverá tristeza ou "felicidade". Umas das imagens para esta novidade do amor cristão, com sua nobre intenção, ainda continua sendo a rosa cantada pelo médico e místico Angelus Silesius:

A rosa é sem porquê, ela floresce, porque ela floresce;

Ela não repara em si própria, não pergunta, se

33 Cfr. M. Scheler, Liebe und Erkenntnis, 83-84; tr. esp., p. 23.

34 Cfr. M. Scheler, Liebe und Erkenntnis, p. 88; tr. esp., p. 32. Para a compreensão do signficado desta reviravolta operada pela compreensão cristão, seguindo as indicações de Scheler, é imprescindível cfr. M. Scheler, Das Ressentiment im Aufbau der Moralen, em especial p. 71-74; tr. por., p 89-94. A seleção destas páginas está restrita aos fins da nossa discussão.

35 M. Scheler, Das Ressentiment im Aufbau der Moralen, p. 71; tr. por., p. 90. a vemos. ${ }^{36}$

Por causa do cristianismo, o amor, então, transforma-se uma manifestação plena de si mesmo como um dom, sem porquê e para quê, a não ser em virtude de si mesmo e como o fim de si mesmo, isto é, de fazer crescer o próprio dom. É esta difusão totalmente indiferente de uma autodoação e, por isto, condescendente e generosa, que faz do amor algo nobilíssimo, talvez, aqui mais nobre que há, de tal modo que pode ser tomado com a essência mesma de Deus. Por isto, certamente, os medievais implicavam na essência do bem supremo a ideia do amor, pois bonum diffusivum sui, isto é, tender, por sua própria natureza, a difundir-se ${ }^{37}$. E trata-se de uma difusão cunhada na própria criação, de tal modo que esta seja as sombras, os vestígios e, no ente humano, a imagem e a semelhança do divino, mas, sobretudo, inscrita no mistério trinitário da essência divina na forma de processão e comunhão consubstancial de pessoas num ato de amor. Donde há criação, então, há interrelação de amante e amado, mesmo que a última parte não ame na mesma ordem e generosidade do amor divino. Amor, porém, sempre haverá, seja em Deus ou na própria criatura, pois amor é ser, no modo que ele mesmo se manifesta e se realiza, cada vez, segundo o modo próprio de dar-se a conhecer em cada esfera, mas, paradigmaticamente, na esfera espiritual como pessoa(s) divina(s). Pessoa, de fato, é amor, que, portanto, não só pode ser conhecida ou compreendida num ato de amor ${ }^{38}$. Em todo caso, resumindo o cerne e a novidade desta compreensão:

Não existe mais nenhuma ideia de um "bem mais elevado", que teria um conteúdo para além e independente do ato de amor mesmo, bem como de seu movimento. O próprio amor é a melhor de todas as coisas boas! Não uma coisa de valor, mas um ato de valor. O próprio valor do amor enquanto amor é o summum bonum agora; não enquanto o que ele efetua e realiza, mas de modo a que toda a realização tenha valor apenas enquanto símbolo, fundamentos do conhecimento de seu ser na pessoa. Deste modo, Deus se torna, por si mesmo, "pessoa", que não possui "nenhuma ideia de bem”, nenhuma "ordenação plena de formas",

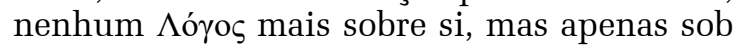
si, como consequência de seu ato de amor. E ele se torna mesmo "Deus amante". ${ }^{39}$

Todavia, em vista do diálogo que motiva a presente discussão, deve-se indicar a proveniên-

36 Angelus Silesius, Il pelegrino Cherubico, versione italiana com testo tedesco a fronte, Milano: Paoline: 1992: Die Ros ist ohn Warum, sie blühet, weil sie blühet,/ Sie acht nicht ihrer selbst, fragt nicht, ob man sie sieht”. A tradução acima é de J. T. Menezes apud M. Heidegger, O princípio do fundamento, Lisboa: Piaget, 1999, p. 59.

37 Cfr. Bonaventura, Itinerario della mente in Dio, p. 128; tr. por., p. 86. Como bem informa o texto da edição crítica, o princípio bonum diffusivum sui provém do Pseudo-Dionísio Aeoropagita, precisamente de sua obra De divinis nominibus, c. 4 \$ 1 .

38 Cfr. M. Scheler, Die Stellung des Mensches in Kosmos, p. 39; tr.por., p. 46.

39 M. Scheler, Das Ressentiment im Aufbau der Moralen, p. 73; tr. por., p. 92-93. 
cia desta imagem cristã do amor. Caraterizada pela inversão do seu movimento, esta não nasce, considerada a partir de sua raiz e origem, de uma inusitada impostação teorética na história das ideias acerca da relação amor-conhecimento, como se fosse uma concepção original dos primeiros teólogos cristãos e pudesse ser caracterizada simplesmente como uma sistemática conexão de sentenças acerca daquela inversão, mas que, por terem a fé por objeto de discussão teórica, seriam fundadas em doutrinas ou dogmas cristãos. Bem pelo contrário, os conceitos filosóficos e teológicos a respeito da reviravolta histórica operada pelo cristianismo em torno do amor chegam posteriormente, a ponto que a tentativa de traduzir sua fonte e origem se prolonga por séculos, criando uma tradição que pode ser remetida para Agostinho, como marco inicial deste esforço. Este empenho, então, perfaz-se como história do espírito, mesmo que, ao longo desta história, muitas vezes, tenha-se obscurecido a evidência e intuições fundamentais da compreensão que funda o projeto desta tradução da fonte em límpidos conceitos - trabalho sem o qual não se eleva, nem se clarifica para os homens de uma época o espírito que anima a sua existência histórica; até quando a fonte mesma tenha tido suas águas, outrora transparentes, turvadas pelo ódio do ressentimento. O esforço de Scheler, no seu embate com Nietzsche, para demonstrar que o ethos cristão não cresce no solo do ressentimento, mas sim com a moral burguesa $^{40}$, a qual finca as suas raízes neste chão, sobretudo quando esta veste o ódio ressentido com a nova roupagem do amor humanitarista e universalista, isto é, com a "ideia e o movimento do amor aos homens em geral" ${ }^{41}$, revela que a revolução do amor cristão foi esquecida às custas do aplainamento que nega qualquer hierarquia e movimento de alto a baixo, de superior a inferior (e vice-versa). Diagnosticando este esquecimento, ele também demonstra que o fundamento da revolução na imagem do amor não repousa na autêntica estrutura da subjetividade humana, menos ainda na genialidade de algum sujeito de conhecimento ou de uma perspectiva de análise objetiva da fé. Se houve tal transformação moderna no conceito de amor, certamente, na base desta pode-se encontrar outra possibilidade do homem experimentar seu viver (e morrer) ao estabelecer relações com o mundo e o divino, as quais são formas de expressão das típicas tendências internas e intencionalidade do viver do homem moderno. É em busca de explicitá-las, que as análises fenomenológicas de Scheler descrevem o modo de vida deste homem como sendo guiado prioritariamente, por exemplo, pelo impulso do trabalho e do lucro ${ }^{42}$, pela valoração ética segundo a qual toda aquisição própria é fruto de seu esforço e suor, não obstante a predisposição operada pelas aptidões naturais, tendo por consequência a completa subordinação dos valores da vida aos valores da utilidade ${ }^{43}$. Assim, desta situação a nós bastante próxima e dema-

40 Cfr. M. Scheler, Das Ressentiment im Aufbau der Moralen, p. 70, 75; tr. por., p. 88-89, 94.

41 M. Scheler, Das Ressentiment im Aufbau der Moralen, p. 96; tr. por., p. 120. Grifo de Scheler.

42 Cfr. M. Scheler, Tod und Forteleben, p. 28-29; tr. por., p. 36-37.

43 Cfr. M. Scheler, Das Ressentiment im Aufbau der Moralen, em siadamente familiar, entrevê-se que as mudanças em perspectivas teóricas e na direção de concepção dos conceitos são acompanhadas e propiciadas por transformações drásticas no modus vivendi ou, mais rigorosamente, no ordo amoris que revela determinado contexto histórico de expressão de significabilidade da vida, sobretudo quando aquelas mudanças indicam uma ruptura com o passado e o surgimento de outra época histórica. A nova imagem do amor, portanto, não é meramente uma tendência a mais de atividade teorético-especulativa, a ser datada cronologicamente como invenção tipicamente medieval e que, assim, já teria sido superada pela exatidão e progresso das modernas ciências, talvez, pela última descoberta da biologia ou a mais recente teoria psicológica acerca dos afetos e emoções. Antes, a fonte da transformação da imagem do amor deve ser procurada na sondagem da estrutura vivencial que se conforma como experiência e se transmite, em cada época, mediante específica atitude interior dos homens diante da vida e da morte.

De onde, então, brota esta nova imagem do amor? Qual a fonte dos conceitos que a delimitam em seus traços? A resposta é entrevista nesta afirmação que, de relance, toca o debate em torno da possibilidade de uma "filosofia cristã" e discute o sentido fundamental do pensamento que, historicamente, se conformou sob as exigências e perspectivas do $\lambda$ ó $\gamma \circ \zeta$ da fé (a teo-logia): “com estas palavras não se entende, como de costume, uma filosofia grega com ornamentos cristãos, mas sim um sistema de pensamento surgido da raiz e a essência da vivência cristã fundamental, mediante a consideração pensante de si mesma (selbstdenkerische Betrachtung) e sondagem (Erfoschung) de mundo" 44 . Nesta anotação, a raiz e a essência correspondem às vivências que estruturam a experiência da vida cristã, indicando que a fonte da nova relação do amor e do conhecimento se encontra na estrutura vivencial que delimita a experiência cristã de Deus e o mundo. É que, como ensina Heidegger, a teologia é "autointerpretação conceitual da existência crente" 45 , no sentido que ela "objetiva" a atinência existencial do crente para com aquilo que se crê e tal "objetivação" não possui outro fim que conformar tal atinência. Por esta razão, a teologia não é ciência da fé só em virtude do fato que se toma a fé por objeto temático, mas principalmente porque ela mesma brota da fét ${ }^{46}$. Assim, alcança-se o núcleo da teologia cristã e seus conceitos, se a toma como consideração de um objeto em que ela necessariamente toma parte, por defini-la, de tal modo que ela é um dar a si em conceito para si mesma desde a sua positividade e possibilidade: uma relação crente-existencial com o Crucificado. Abstraindo-se do problema se a ideia de uma "filosofia cristã", por ser essencialmente teo-lógica, não vai além de um contrassenso, como a ideia de um círculo quadrado ${ }^{47}$, dito a partir da tendência da fenomenologia de Scheler, os conceitos

especial p. 115-16, 131-32; tr. por., p. 145, 163-64

44 M. Scheler, Liebe und Erkenntnis, 87; tr. esp., p. 28.

45 Cfr. M. Heidegger, Phänomenologie und Theologie, in Wegmarken, Frankfurt a. M.: Klostermann Seminar, 2004, p. 56; tr. por., Fenomenologia e teologia, in Marcas do caminho, Petrópolis: Vozes, 2008, p. 66.

46 Cfr. M. Heidegger, Phänomenologie und Theologie, p. 55; tr. por, p. 66.

47 Cfr. Heidegger, Der europäische Nihilismus, in Nietzsche II, Sttutgart: Neske, 1998. p. 116; tr. por., O niilismo europeu, in Nietzsche II, Rio de Janeiro: Forense Universitária, 2007, p. 97-98. 
da fé são modos em que a vida se expressa ao vivenciar e compreender a si mesma a partir de um evento primordial, o aparecimento de Cristo, porém, como a pessoa na qual Deus dá a conhecer sua verdade mais íntima com sendo, fundamentalmente, um ato de amor misericordioso e criador ${ }^{48}$. Por consequência, os conceitos teológicos têm que ser reconduzidos para o conjunto de vivências pelas quais se estrutura, na sua totalidade, o nexo das relações do homem sob o primado do amor, inclusive ante o conhecimento, enquanto ato primordial e intenção fundamental das vivências. Criação e graça, redenção e salvação, conversão e imitação, pecado e condenação, entre outros conceitos, são prenhe de significados somente na remissão a este conjunto estruturante da vida humana em suas vivências do divino e do mundo, em contínua organização por meio do dinamismo do amor, mas que possui, como princípio primeiro, a essência divina como ato de amor.

Os traços desta estrutura vivencial, em que se traduz a exploração do sentido da vida humana sob a ótica do amor, Scheler crê serem passíveis de ser explicitados, com rigor e fundamentos ainda não vistos, por meio de análises fenomenológicas. Contudo, este é um velho propósito, como dito, gerador da história, vez que está na base do surgimento da dogmática cristã, embora sob outras bases metodológicas e hermenêuticas, na medida em que, por exemplo, um dos principais intentos de Agostinho consistiu na tentativa de desentranhar os traços desta estrutura fundamental, bem como ultrapassa o alcance da(s) escola(s) e pensadores que se alinham no mesmo propósito. Excetuando a tradição místico-edificante, "somente em Santo Agostinho e sua escola encontramos vigorosas tentativas iniciais para ganhar uma transplantação imediata do conteúdo vivencial cristão nos conceitos filosóficos"49, escreve Scheler. E acrescenta, especificamente em relação à primazia do amor: "unicamente em Santo Agostinho e na tradição agostiniana até Malebranche e Blaise Pascal encontramos sérios princípios de captar conceitualmente a vivência fundamental cristã acerca da relação amor e conhecimento, também em conexão com problemas extrarreligiosos $"{ }^{50}$. De outro lado, o fenomenólogo não deixa de reconhecer que a história deste propósito nem sempre conheceu logros, desde o seu início, "em razão da profunda dependência de Santo Agostinho em respeito ao neoplatonismo" e, ao mesmo tempo, por ter sido obstruída "por meio de sua vontade autoritária - ainda que sua vontade especulativa a transcenda - em favor da unidade da instituição eclesiástica". Também o debate entre franciscanos e tomistas, ao opor intelectualismo e voluntarismo, "passa completamente ao largo da genuína estrutura vivencial cristã de Deus e o mundo" 51 , mas de tal modo que nem mesmo a tradição franciscana não a teria apreendido, mesmo com a vantagem de ter a seu favor e por referência necessária da concepção dos conceitos filosófico-teológicos a experiência mística de Francisco de $\mathrm{Assis}^{52}$, fundada no encontro amoroso com o Crucificado e que desemboca

48 Cfr. M. Scheler, Liebe und Erkenntnis, 88-90; tr. esp., p. 32-33. 49 M. Scheler, Liebe und Erkenntnis, 88; tr. esp., p. 31. A citação prossegue após a intercalação da seguinte.

50 Cfr. M. Scheler, Liebe und Erkenntnis, 94; tr. esp., p. 41

51 M. Scheler, Liebe und Erkenntnis, 93; tr. esp., p. 40-41. Inclui a próxima citação.

52 Nesta perspectiva, é paradigmática a obra de Boaventura de Bagnoregio, segundo a interpretação de La fisosofia di San Bonaventura. Milano: Jaca Book, 1994. p. 66-85, em especial 69-76. Nestas capítulo, o autor coloca o problema de como traduzir a experiência mística de Francisco e sua via extática de união com Deus, advinda nos constantes êxtases espirituais, como o verdadeiro problema bo- na relação fraternal e cósmica com as criaturas, como se vê: "a singular renovação da vivência fundamental cristã em Francisco tão pouco foi capaz de engendrar nenhuma versão conceptual-filosófica mais adequada para ela". $\mathrm{Na}$ continuidade desta história de permanentes recomeços em torno desta questão, Scheler se insere, porém, no horizonte aberto pelo método fenomenológico. É o que vem à tona no prólogo de Vom Ewigen im Meschen:

Esse conhecimento [natural de Deus] só cumprirá tal tarefa [unificadora do pensamento religioso-filosófico] se liberar o cerne do agostianismo de seus invólucros histórico-temporais, fundamentando-o de maneira nova e mais profunda por intermédio do pensamento da filosofia fenomenológica; ou seja: da filosofia que empreende a visualização dos fundamentos essenciais de toda existência com olhos purificados e deduz a mudança de uma cultura por demais intricada trouxe para si em meio a símbolos sempre novos. Nesse caso, ele representará sempre mais claramente aquele contato imediato da alma com Deus; um contato cujos rastros Agostinho sempre buscou acompanhar novamente com meios do pensamento neoplatônico e sempre se esforçou por expressar uma vez mais em palavras. Somente uma teologia da experiência essencial do divino conseguirá abrir novamente os olhos para as verdades perdidas de Agostinho ${ }^{53}$.

Assim, a meta de compreender o movimento do amor e seu papel na fundação do conhecimento imediato do divino e das coisas não mais se coloca dentro da circunscrição dada pelo sentido da interrogação pelo ser absoluto posto pela teologia inerente ao pensamento metafísico substan-

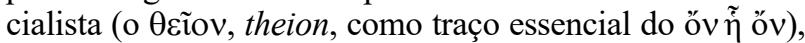
mas de uma teologia experiencial do divino, que remete, de novo, para o imperativo de compreender a estrutura fundamental da vivência cristã. Em todo caso, é importante perceber que o esforço de remeter os conceitos teológico-filosóficos à fonte da experiência cristã de Deus e do mundo, revelando a sua estrutura vivencial fundamental, não consiste apenas em concebê-la eideticamente, como diria Husserl, a partir daquilo que se doa a partir de si mesma, garantido que a elaboração conceitual desta experiência se funde "numa doação originária que apreende a essência (Wesen) em sua ipseidade de 'carne e osso' (leibhaften Selbstheit)" ${ }^{\prime 4}$. É indubitável que, com este retorno à fonte, está em mira apreender a vida cristã em sua própria vivacidade, no movimento autorremissivo e experiencial em que ela vive ou vivencia a si mesma e constitui o intricado contexto de relações (também vivenciais) com o divino, com os homens e tudo mais, e não tanto a vida reificada com o objeto histórico do conhecimento. Justamente por isto, ao mesmo tempo, está em questão apreender o que e como, nesta estrutura dinâmica e essencial, doa-se aquela inversão na direção do movimento constituinte do amor. Nesta

naventuriano.

53 Cfr. M. Scheler, Vom Ewigen im Menschen, GW 5, Bonn: Bouvier, 2007, p. 8-9; trd. por., Do eterno no homem, Petrópolis: Vozes, Bragança Paulista: 2015, p. 9.

54 E. Husserl, Ideen zur einer reinen Phänomenologie und phänomenologischen Philosophie, Hamburg: Felix Meiner, 2009, p. 15; Ideias par auma fenomenologia pura e para uma filosofia fenomenológica, Aparecida: Ideias \& Letras, 2006, p. 37. 
direção, a inversão, como o núcleo e sentido das vivências pelas quais a vida se compreende no curso de sua experiência, seria aquilo que conforma a vida cristã como uma resposta amorosa e a (re)ordena a partir dos fins de seus atos afetivos como atos primários e originadores dos demais ${ }^{55}$. A inversão do movimento precisa se mostrar como a experiência da inversão ou, melhor, a experiência da inversão do humano amor com seus afetos e preferências enquanto o reflexo da inversão do amor divino (entendida como a manifestação da essência divina), caso contrário àquela recondução dos conceitos à estrutura fundamental da vivência cristã encontraria algo vazio ou seria somente um artifício metodológico.

É necessário, então, que a inversão (do amor divino), de vivência em vivência, torne-se a experiência reconfiguradora da vida humana em seu ordo amoris, mostrando a vida humana em seu dinamismo vivencial como a inversão consonante àquela inversão primeira em princípio e nobreza. Na verdade, esta reordenação da estrutura é a reversão à condição mais originária da vida humana se perfazer sob a ótica da fé, o que, com os termos medievais, diz-se com o termo conversio, -onis, conversão. Não se trata, porém, de uma mudança no sentido de melhoria da pessoa humana nem de um câmbio da sua individualidade ou singularidade, mas sim de um giro em direção para aquilo que sempre foi, ao originário de sua condição de criatura ${ }^{56}$, porém, que, no curso das vicissitudes da história de realização de sua finitude histórica-corporal-espiritual, perdeu-se da via (pre)destinada no amor divino e se encontrou noutra condição de débito ontológico para com seu ser. Tal giro é, pois, uma viragem para si, para a sua possibilidade mais autêntica de ser-criatura, que se opera mediante uma inversão na ordem do(s) próprio(s) amor(es). Para indicar esta mudança de orientamento, que reconfigura a estrutura da vida humana desde a sua raiz e essência, as confissões agostinianas são exemplares, na medida em que são reminiscências que querem recordar as desordens da juventude e as vicissitudes de sua busca não para amar as "torpezas passadas e as depravações carnais", mas sim, como diz Agostinho no seu diálogo com Deus, "para Vos amar, ó meu Deus" ${ }^{57}$. É com o fim da conversão de certos amores para outro amor que se faz a memória de seus descaminhos e na reminiscência mesma encontrar a verdade e a beleza divina como o bem mais amável e desde antes aquilo realmente procurado e desejado em modo errante em amores inferiores. Como se poderia descrever, porém, ao menos em largos traços, esta experiência da inversão no movimento do amor inaugurada pela compreensão cristã? Indicamo-la, agora, a partir de Agostinho.

\section{A inversão cristã do movimento do amor}

55 Cfr. Cfr. M. Scheler, Liebe und Erkenntnis, 95-96; tr. esp., p. 44-45, em que se indica o amor como um ato espiritual que está na base atos intelectivos e imaginativos, cuja precedência já fora pensada por Agostinho, adiantando conclusões da moderna psicologia. Cfr. também M. Scheler, Vom Wesen der Philosophie und der moralischen Bedingung des philosophischen Erkennens, p. 79-81; tr. por., 105-107, em que se indica que os atos perceptivos e outros, como a recordação, a expectativas são antecedidos por uma doação valorativas de seus correlatos, como também o ato de julgar pressupõe o conhecimento de valor, de modo que o "amante" precede o "conhecedor".

56 Cfr. H. Rombach, Strukturanthropologie. »Der menschliche Mensch«, Freiburger/München: Karl Alber, 1993, p. 30-31; tr. esp., El hombre humanizado, Antopología estructural, Barcelona: Herder, 2004, p. 32-33.

57 Aurelius Augustinus, Confessionum, II, 1, 1; tr. por., p. 45.

\section{enquanto experiência reorientadora do ordo amoris a partir de Agostinho.}

A busca, rememorada por Agostinho ao longo de suas Confissões, deseja encontrar o amor primordial capaz de saciar plenamente o desejo da felicidade ou beatitude. Esta possui a estrutura de um quaerere, isto é, de uma interrogação ou investigação movida pela aspiração e tendência de conhecer "quem é Deus?", que se faz junto às criaturas e ao ânimo humano ${ }^{58}$. Na sua elaboração, a busca se faz na progressiva passagem das primeiras instâncias dos amores às criaturas por elas mesmas, por causa da beleza delas, para o centro de onde brotam os amores ou o "coração" da alma humana, então, do âmbito sensível para a dimensão espiritual enquanto o que há de mais profundo e desconhecido no homem. Sem desprezar a beleza das criaturas, por serem perfeições divinas que já se dão aos sentidos, a questão é investigada, portanto, na inversão da procura em função do homem exterior que pergunta às criaturas para a direção que se cumpre de modo mais originário com a interrogação do homem interior: Et ecce intus et ego foris et tibi quaerebam, "Eis que habitáveis dentro de mim, e eu lá fora a procurar-vos" resume Agostinho. Por causa deste giro, a questão pela essência da pessoa divina também inclui, na sua elaboração prévia, a questão "quem sou?", no sentido de uma interrogação pela essência do próprio ser: Factus eram ipse mihi magna quaestio ${ }^{60}$. Uma conversão da questão, pois. Não obstante, o questionado originário permanece sendo Deus. A busca pela essência divina, entrementes, deve ser pensada em conexão com a interrogação dos revezes da singularização da condição humana: "Sob o Vosso olhar transformei-me, para mim mesmo, numa questão (mihi quaestio factus sum) que é minha própria enfermidade" 61 Pois, o amar e conhecer a Deus pressupõe a compreensão do modo pelo qual o homem se destina e se desvia de si e de Deus mediante seus afetos e preferências, evitando ou não a questão.

Em todo caso, somente ali, no núcleo da alma, "na vida da própria vida" diante a reminiscência da memória, a verdade divina que a habita ${ }^{63}$ e a ultrapassa, residindo para além e acima do espírito humano ${ }^{64}$. Por isto, então, é na memória que o homem regressa para o que ele sempre amou e aspirou encontrar, a vita beata, atingindo aquele gaudium do conhecimento da verdade ${ }^{65}$. Na memória, todos os homens, que são viandantes neste mundo e companheiros na via(gem) da vida rumo a alegria da felicidade em Deus ${ }^{66}$, regressam para sua fonte e origem, que é o (amor do) Criador. Contudo, não é a memória a fazer o homem convergir progressivamente todas as suas forças e tendências para a fonte de amor $^{67}$. mas sim o amor que move a boa vontade do 58 Aurelius Augustinus, Confessionum, X, 6, 8-10; tr. por., p. 22123.

59 Aurelius Augustinus, Confessionum, X, 27, 38; tr. por., p. 243. 60 Aurelius Augustinus, Confessionum, IV, 4, 9; tr. por., p. 243.

61 Aurelius Augustinus, Confessionum, X, 33, 50; tr. por., p. 251.

62 Cfr. Aurelius Augustinus, Confessionum, X, 6, 10; tr. por., p. 243. A vida da vida é Deus. De modo que a palavra vida, repetida na segunda posição, possui o significado de amima.

63 Cfr. Aurelius Augustinus, Confessionum, X, 25, 36; tr. por., p. 242.

64 Cfr. Aurelius Augustinus, Confessionum, X, 26, 37; tr. por., p. 242.

65 Cfr. Aurelius Augustinus, Confessionum, X, 21, 30-31; tr. por., p. 238-39.

66 Cfr. Aurelius Augustinus, Confessionum, X, 4, 6; tr. por., p. 220.

67 Cfr. o segundo capítulo de H. Arendt, $O$ conceito de amor em 
homem em ser feliz em Deus, de tê-lo como o único bem verdadeiro e estável em meio aos demais passageiros ${ }^{68}$, à medida que queira existir na referência retrospectiva com ele. Esta relação retrorreferncial é dependência da criatura ao Criador, mas, sendo interrelação entre pessoas espirituais, trata-se de um vínculo no amor. Então, é o amor mesmo que opera aquela reversão da existência humana e a reordena conforme o seu princípio e fim: o amor divino. Com esta reversão que inverte a ordem das preferências, antepondo a beleza e verdade do Criador a qualquer outro bem inferior, torna-se patente o que o homem é segundo a essência de seu ser e possibilidade enquanto criatura. Por esta razão, as confissões de Agostinho reconhecem que o fruto principal de suas reminiscências não é fazer ver o que ele foi, mas quem ele é ele mesmo ou, dizendo em primeira pessoa, "não o que fui, mas o que já e o que ainda sou" 69 . Este ainda-sou é o que se conservou, por ser o mais próprio do humano ou sua ipseidade, em meio aos desvios da busca e investigação que é cada homem, mas que permanece ainda por se realizar no reenvio da condição individual e histórica da criatura humana. O já-sou, então, é ainda a possibilidade de ser, não a partir de uma idealização moral, mas como realização de algo passado e ainda presente, como sempre rementido à origem e fonte amorosa, porém, na liberdade, esquecido e apagado da memória, na medida em que o homem, na maior parte das vezes, não ama as criaturas e a si mesmo na ordem reta do amor em Deus, por Deus e para Deus. Daí a necessidade do homem inverter seu ordo amoris, revertendo-o para a origem que o habita, como um salto para a profundeza desconhecida que há em si. E, para isto, a conversão exige querer converter todas as suas capacidades sensitivas, psíquicas e intelectuais, convergindo-as para o conhecimento e fruição da verdade eterna e absoluta.

A conversão, então, é uma remissão do homem para o seu ser, cuja essência, utilizando a expressão já assinalada de Scheler, é um ens amans. Contudo, o que o homem é faticamente, na sua situação histórica e individual, nem sempre se expressa como a possibilidade de ser aquilo que já é enquanto criatura. Certo, o homem jamais deixa de $\operatorname{amar}^{70}$, mas, na maioria das vezes, ama o mundo de um

Santo Agostinho, Lisboa: Piaget, 1997. Afirma a autora: "A vida feliz encontra-se, em primeiro lugar, na memória; através dela, o homem está em relação como o seu ser mais apropriado, a sua origem. (...) A dependência da vontade de ser feliz exprime uma dependência mais profunda e mais fundamental do que aquela que o desejo jamais revelar por si próprio" (p. 68). Nesta direção, a dependência da criatura enquanto vínculo interpessoal no amor é algo mais originário que a recordação da vida feliz.

68 Cfr. Aurelius Augustinus, De libero arbitrio, I; 12, 28-29; tr. por., O livre arbítrio, Braga: Faculdade de Filosofia, 1986, p. 242.

69 Cfr. Aurelius Augustinus, Confessionum, X, 4, 6; tr. por., p. 220. 70 Importante realçar que, para o pensamento agostiniano, o amor não é simplesmente um ato que homem decide realizar ou não, mas sentido ou tendência fundamental que conduz a vida humana na sua totalidade, tal como expressa É. Gilson, Introdução aos estudos de Santo Agostinho, p. 258: “(...) nada seria menos razoável do que pretender isolar o homem de seu amor, ou impedir que o use; igualmente, isolá-lo de si e impedi-lo de ser ele mesmo. Subtraído do homem o amor que lhe entranha de objeto em objeto em direção a algum fim confusamente pressentido, necessariamente teremos um corpo material, que, ao menos cede ao seu peso. O problema moral [enquanto questão da totalidade do homem e princípio de todos os atos da alma humana] que se coloca não é, portanto, saber se é necessário amar, mas o que é necessário amar". Disto decorre a primeira conclusão: não se trata de definir paixões humanas boas e más e sim a intenção que as anima, pois "tudo depende do amor que os inspira. Do mesmo modo, é um erro acreditar que haja objetos bons e maus em si mesmos" (p. 257). Nesta perspectiva, para o homem, o cerne da questão acerca si mesmo e do retorno ao sentido modo que não lhe permite unir-se no amor à sua fonte $\mathrm{e}$ origem; ama a si e as demais criaturas buscando nelas a sua felicidade ${ }^{71}$. Por isto, este ser-o-que-sou - modo de ser que, enquanto possibilidade de singularização e finitização da pessoa humana, também é o-que-ainda sou, entendido como ainda-ter-que-ser - deve cindir-se do o-que-fui, na medida em que são modos radicalmente diferentes do homem ser no mundo ou fazer dele sua morada. Este último, o-que-fui corresponde ao modo de ser em que se estabelece, mediante o ordo amoris, determinada pertinência ao mundo. Este pertencer particular ao o-que-fui é um falar a linguagem do mundo, porque os homens que a estabelecem somente possuem ouvidos e olhos para as criaturas ${ }^{72}$, para os bens inferiores. Referem-se e se comportam para as criaturas que compõe o mundo não a partir da asculta e visão do "coração", atos que provém do espírito, mas sim daqueles ver e ouvir que é próprio dos sentidos e, portanto, não ultrapassa a beleza terrena, nem alcança por meio da visibilidade desta beleza o invisível do mistério divino ${ }^{73}$. Por isto, o-que-fui caracteriza um modo de ser que, na base dos textos joaninos, é nomeado no plural, isto é, na sua estrutura comum, como por dilectoris mundi. Quem, porém, destina a si mesmo na singularização de sua pessoa neste modo de ser é, no todo de sua condição finita com seus aspectos particulares, um amante do mundo. No sentido deste modo de ser, mundo já não possui valoração positiva das criaturas, mediante as quais Deus revela a sua perfeição, a qual necessita ser amada; não é mais a plenitude de céus e terra, em que se resplandece o amor divino ${ }^{74}$. Antes, mundo adquire um sentido que remete para o desvigoramento do ser-criatura humano com suas potencialidades espirituais no seu dirigir a todos os entes criados por Deus, na intencionalidade de se salvarem da impermanência da vida no gozo das coisas que passam, isto é, daquilo que se poderia apenas utilizar $^{75}$. Mundo passa ser, então, o conjunto de obras dos

mais próprio de ser si mesmo é o modo como ama, a intencionalidade desde a qual ordena todo o seu viver.

71 Cfr. Aurelius Augustinus, In epistolam Ioannis ad Parthos Tractatus decem, II, 11.

72 Cfr. Aurelius Augustinus, In epistolam Ioannis ad Parthos Tractatus decem, VII, 3.

73 Cfr. Aurelius Augustinus, In epistolam Ioannis ad Parthos Tractatus decem, IV, 5; VII, 10.

74 Cfr. Aurelius Augustinus, In epistolam Ioannis ad Parthos Tractatus decem, II, 12; IV, 4;. No sentido deficiente, mundo é casa que os homens constroem junto a totalidade da criação por meio de atos de amor ou dilecção que, na verdade, não é amor em sentido mais próprio, pois caracterizado na ordem do desejo e da ambição: desiderium carnis, desiderium oculorum, et ambitionem saeculi. Este modo de amar, como se acentuará, é apenas a tentativa do homem fugir da precariedade da vida humana revelada na dor e no sofrimento, da transitoriedade das coisas e da própria mortalidade, amando o finito e mutável como se fosse eterno e incomutável.

75 Cfr. Aurelius Augustinus, In epistolam Ioannis ad Parthos Tractatus decem, II, 12; De doctrina christiana, I, 3, 3; I, 4, 4; tr. por., p. 42, 44-45. Na vida mortal, somente em Deus é possível a fruição, a dilectio ad fruedum, pois somente no Criador o homem pode encontrar o fim de seu amar e conhecer plenos, o que significa alcançar a beatidude, ser feliz. Como antecipação desta vida plenamente feliz, tudo o mais deve ser colocado a simples uso (ad utentum) em vista deste fim último, isto é, amadas na justa medida que modera o viver humana para a vita beata. As criaturas, as coisas corpóreas e finitas, portanto, são só meios para atingir as coisas eternas e espirituais. Na reta ordenação do amor, usa-se, portanto, de todos os bens finitos (os bens externos e materiais, o próprio corpo e alma, bem como do outro, em seu corpo e alma, como expressão de amor ao próximo), subordinando os inferiores aos superiores: as riquezas e os bens materiais em vista da vida do corpo; este em função da alma; e tudo isto em utilidade da perfeição do espírito humano e fruição do sumo e eterno bem, o Criador). Todavia, usar as criaturas não possui o significado ordinário ou utilitarista de dispor-se das criaturas segundo 
homens que possuem nas criaturas o em-vista-de-que eles amam, isto é, em vista das criaturas mesmas ou do gozo que elas podem oferecer, não da vita beata que só se encontra na fruição e conhecimento da verdade de Deus. Por isto, o que-fui é o modo de ser em que os homens se perfazem como mundanos, por terem sido criados como pertencendo ao mundo, porém, presos às criaturas que constituem o universo e, por isso, despidos de uma vontade que não é o querer existir a partir da origem, na dependência do Criador $^{76}$.

Deste modo, o ser-o-que-sou, justamente para liberá-lo propriamente enquanto o ainda-o-que-sou como dom e tarefa de si mesmo, supõe uma libertação daquela pertinência para outro modo de pertencer ao mundo, destinando ou reconfigurando o viver humano a partir de um "como" radicalmente diferente daquele modo de pertinência que é amar o mundo na ordem do desejo concupiscente e ambicioso. A ser superado nesta libertação é o predomínio do desejo ardente por ter as coisas que passam (amor rerum transeuntium) ou por não as perder, se já as possui ${ }^{77}$. Este segundo modo mais originário de singularização da mundanidade, entrementes, não exclui relações no amor com as criaturas, mas sim se constitui a partir de outra intencionalidade, isto é, baseada no em-vista-de-que radicalmente outro. Este rompimento, porém, não é mais que assumir a condição originária da criatura, depois de confessar sua proveniência e dependência do Criador que se se expressa no amor a querer existir, mesmo nos infortúnios e vicissitudes da vida presente, por ser um infortúnio ainda maior não querer existir, já que é nesta existência mundana e ao longo dela que pode regressar ao Criador. Assim, o-que-já-sou, com seu sentido paradoxal de ainda-estou-por-ser-o-que-já-sou, mostra-se como querer reconduzir o viver presente para a sua fonte enquanto um poder inerente ao ser do humano e que somente cada homem singular pode ativá-lo livremente e de bom gra$\mathrm{do}^{78}$ como sendo a seguinte resposta: "eu quero existir", "quero ser de bom grado o que posso ser". E isto, acentua-se, mesmo nas desventuras, para a criatura não ser ainda mais desdita, sobretudo, depois da morte, pois nada é mais infeliz para ela que não poder ser unida (para sempre) ao Criador. E a ingratidão em querer não poder ser, desde já, na dependência do Criador só antecipa este mal ou infortúnio perene. Tanto mais miserável é a criatura, quanto ela não vê que o ipsum esse é o magnum bonum e, nesta cegueira, não dele não se avizinha desta "Existência Suprema" e bondosa mediante decisão de querer existir por

o bel prazer ou gozo. Com efeito, é nesta compreensão de uso que o amor se configura como "amor-próprio", no sentido de um interesse de satisfação do desejo sensível, do desiderium carnis e, então, um modo de amar que refere o homem para as criaturas segundo os imperativos sensualistas do corpo. Não obstante a pretensão de uso pelo gozo, estes imperativos conduzam para a submissão ao que é amado com este amor sensível. É no mero uso e gozo das realidades finitas, portanto, que opera o interesse egoísta de domínio e pulsões que levam à adesão àquilo que é amado, porém, que não é mais que dependência a bens inferiores, não é o justo amor. Este é somente possível, por certo, no aviltamento desta tendência sensualista do viver humano, por meio da ordenação da dilectio guiada por um amor espiritual que eleva o homem para a fruição das coisas superiores e que se detém nas inferiores, exclusivamente, pela afeição que é ad utentum.

76 Cfr. Aurelius Augustinus, De doctrina christiana, I, 12, 12; tr. por, c. $13,12 \mathrm{a}$, p. 52.

77 Cfr. Aurelius Augustinus, De diversis quaestionibus octoginta tribos, 33; tr. it.; Ottantre questioni diversi, disponível em www.augustinus.it, acesso em 25/11/2017.

78 Cfr. Aurelius Augustinus, De libero arbitrio, III, 6, 18-19; tr. por., p. $188-90$ ele e nele ${ }^{79}$. Este querer de poder ser mais oiriginariamente na condição de criatura, então, é ato de amor grato à bondade do Criador, isto é, é o modo de ser justo daqueles que já vivem, por antecipação, a existência presente em vista daquela fruição plena em Deus que constitui a vita beata. Novamente com base nos textos joaninos, estes são assinalados como sendo aqueles que amam a Deus, pois, quem o ama, também o escuta e conhece a sua verdade, buscam-no em toda a parte como os "olhos do coração" 80 e, por isto, são também aquele que o esperam vê-lo imediatamente, face a face. E, assim, são aqueles que vivem na espera de saber perfeitamente, um dia, na plenitude da visão que ultrapassa toda a beleza terrena, quem são eles mesmos, na propriedade de seu ser-criatura ${ }^{81}$. Os que assim amam e deste modo perfazem sua finitude histórico-individual, portanto, são aqueles que pertencem ao Criador. Na verdade, eles não pertencem ao mundo, pois é em vista desta adesão ao Criador que perfazem a sua existência, isto é, o homem é aquela criatura que realiza o seu si mesmo tanto mais propriamente quanto mais ordena sua existência em vista de fruir e amar a Deus, num total referimento de seu ser para a vida incomutável ${ }^{82}$. Contudo, é neste em vista-de-que (de pertencer ao Criador em um amor e fruição que não cessa) eles realizam a própria mundanidade e se comportam com tudo o que forma o mundo enquanto totalidade do criado:

$\mathrm{Na}$ realidade, quanto mais amor tiveres a existir, tanto mais desejará a vida eterna, e anelarás moldar a tua pessoa de tal maneira que as tuas disposições não sejam temporâneas, impressas em ti e gravadas a partir das afeições às realidades temporâneas. Estas realidades temporâneas, antes de existirem não são nada; quando existem, passam; e tendo passado, deixam de existir. Deste modo, quando são futuras, ainda não existem; quando são passadas não existem. Como pois sustê-las a fim de permanecerem, realidades para as quais começar a existir é caminhar par ao não existir? Mesmo assim, quem ama a existência preza estas realidades na medida em que existem (in quantum sunt), e ama o Ser que sempre existe (amat quod semper est). E se [antes] era volúvel no amor dessas realidades, fimar-se-á [agora] no amor deste Ser; e se se derramava no amor das coisas transientes (amore transeuntium), condolidar-se-á no amor do Ser que permanece (permanentis amore). Manter-se-à fixo, e alcancançará essa existência que pretendia, quando receava deixar de existir, e quando enredado pelo amor das coisas que passam, não conseguia manter-se fixo ${ }^{83}$.

A experiência da inversão do sentido do amor cristão, nestes termos, aparece como a solidificação da existência na própria finitude, à medida em que, paradoxal79 Cfr. Aurelius Augustinus, De libero arbitrio, III, 7, 20; tr. por., p. 191-92.

80 Cfr. Aurelius Augustinus, In epistolam Ioannis ad Parthos Tractatus decem, VII, 10.

81 Cfr. Aurelius Augustinus, In epistolam Ioannis ad Parthos Tractatus decem, IV, 5 .

82 Cfr. Aurelius Augustinus, De doctrina christiana, I, 22, 21; tr. por., p. 59.

83 Aurelius Augustinus, De libero arbitrio, III, 7, 21; tr. por., p. $192-92$. 
mente, o viver se firma ou se enraíza no eterno - enquanto algo digno de ser absolutamente amável por estar plenamente convencido em reta fé ser aquilo que nem mesmo a morte poderá lhe retirar ${ }^{84}$-, graças a um câmbio radical àquilo que a que se quer pertencer. Justamente para levar à plenitude esta pertinência, a inversão se dá como conversão das múltiplas referências e tendências do viver humano a tudo mais a partir de uma ordem que confere ao incomutável a sua devida prioridade tanto no conhecer como no amar. Como tal transformação na pertinência, a inversão é a experiência de retorno como passagem de um caminho de volta da pertinência à qualquer espécie de res temporalia para a aquele tomar parte no quod semper est, isto é, para se inserir mais decidamente naquela esfera de ser mais originária, da qual toda criatura já depende por existir $a b$ alio. Este regresso à pertinência a Deus, que é o reestabelecimento da relação primeva do próprio ser do homem no seu estado de criatura para com a origem, implica necessariamente a modificação na natureza do amor: do amore transeuntium para o permanentis amore.

Certamente, trata-se de uma pertinência que nasce por eleição do Criador como ato amor, já que segundo a compreensão do viver cristão, que este elabora de si, somente é possível amar a Deus porque ele primeiramente amou a criatura ${ }^{85}$, o que vem teologicamente ao conceito como a prioridade da graça divina sobre os méritos hu$\operatorname{manos}^{86}$. Então, toda debilidade neste amor é, no fim, deficiência na correspondência ou, mais precisamente, na intentio da resposta humana ao ato divino que, por essência e perfeição, precede ao ato humano. Por consequência, não é não por graça dos desejos despertos pela sensibilidade, que o reordenamento do ordo amoris acontece, pois, estes, sem a orientação da intenção espiritual, inevitavelmente, aprisionam o homem na pertinência ao mundo segundo a direção imprópria de consumação da mundanidade dos homens, isto é, no sentido de estar no mundo em vista do mundo mesmo ou por (a)mor das criaturas. Mas também não é, exclusivamente, em virtude da humana boa vontade, mesmo que à ausência desta vontade boa se possa remeter a origem e fonte de todo mal, pois no querer se afastar do bem incomutável, voltando-se para um bem privativo ou um bem inferior, o homem desordena a originária estrutura ontológica do universo e da interrelação dos bens e, assim, na deficiência de sua liberdade, desvirtua o sentido do seu viver no mundo no modo de ser do homo superbus, et curiosus, et lacisvus ${ }^{87}$. Assim, não obstante a vontade boa eleve homem para acima da condição do viver regido pelas pulsões e pelo olhar concupiscente pelas belezas das criaturas, somente um amor que transpasse o viver humano, puramente espiritual, é capaz de reconfigurar seu ser e existência. Por outro lado, na raiz da vontade mesma opera um amor como sendo a sua força e tendência interna, fazendo o homem mover para diferentes bens. Para que a vontade queira sentir, imaginar ou pensar algo, com efeito, ela precisa primeiramente tender, em um ato de amor, para o que quer, ou seja, atentar, ponderar e, por fim, eleger como importante algo

$\overline{84}$ Cfr. Aurelius Augustinus, De diversis quaestionibus octoginta tribus; $34,2$.

85 Cfr. Aurelius Augustinus, In epistolam Ioannis ad Parthos Tractatus decem, VII, 7.

86 Cfr. Aurelius Augustinus, In Evangelium Ioannis Tractatus Centum Viginti Quatuor, 86, 2; tr. it.; Commento al Vangelo di San Giovanni, disponível em www.augustinus.it, acesso em 25/11/2017. 87 Cfr. Aurelius Augustinus, De libero arbitrio, II, 19, 53; tr. por., p. 157. a ser desejado, imaginado ou pensado. Assim, este amor, do mesmo modo que o peso faz o corpo tender para o seu lugar de repouso, arrasta homem em todas as dimensões de seu viver para os bens: pondus meum amor meus; eo feror, quocumque feror, "o meu amor é o meu peso. Para qualquer parte que eu vá, é ele que me leva" ${ }^{88}$. Mas se na base da boa vontade está o amor que envolve todo o viver do homem, deve haver um amor perfeito que araste o homem para seu lugar de origem ao ponderar o sumo bem como o bem ser amado absolutamente e, assim, ser um amor que deseje senão morar e demorar permanentemente na morada de Deus, in domum Domini. E em virtude deste amor, então, o homem quer poder ser em e por Deus e, por isto, é fundamental para plenificar a copertinência entre criador e Criatura. Mas qual amor é este?

Trata-se de um amor, cuja intenção não é fundada na carência ou no dirigir-se ao outro por causa de sanar uma necessidade do amante. Pois, por mais genuíno que seja o amor baseado nesta intencionalidade, este amor ainda se justifica pelo benefício dado àquele que necessita do bem operado, estabelecendo uma superioridade meritória entre do amante sobre o amado ${ }^{89}$. Um amor mais perfeito e superior em dignidade, já entre os homens, é aquele cuja intenção não é a melhoria da condição do amado, tomando nele qualquer motivo para a ele se voltar e devotar. Tal pressuposição somente pode levar ao amor à condição de humanitarismo, por mais dignas que sejam as suas metas e intenções. A perfeição do amor exige, pois, a liberalidade que cresce a partir da própria liberdade de ofertar-se, o que quer dizer um amor que se movimenta e expande a partir do próprio centro da pessoa que toma a iniciativa de amar. Na lógica cristã, este amor é o $\lambda$ óyo $\varsigma$ do dom, isto é, o dar-se que nasce e cresce por si mesmo e, deste modo, o vir à fala do ser da pessoa desde as profundezas de seu mistério como livre oferta e expressão de si mesma. Segundo a tradição cristã, somente um amor de tal natureza remete o homem a todas as criaturas, em especial, ao seu próximo, num vínculo ao Criador, mas de modo que este amor mútuo não seja de segunda ordem em relação ao amor a Deus, mas sim como sendo o ápice deste amor ${ }^{90}$, pois, nele o amor alarga-se ao ponto de amar não somente o próximo, mas também o próximo mais distante, ou seja, o inimigo ${ }^{91}$. Ademais, é nele que o homem se encontra com o Crucificado, pois ser o único capaz de escutar o Verbo Encarnado, tocá-lo e vê-lo na sua face humana ${ }^{92}$.

Este amor nomeia-se caritas, -atis, que Agostinho define como sendo o aquele amor pelas coisas que jamais são desprezíveis aos olhos de quem $\mathrm{ama}^{93}$. Estas coisas são as eternas, mas também aqueles que as amas, pois o amor pelo eterno, que é Deus, também eterniza quem o "possui" e o conhece neste amor ${ }^{94}$. Nesta forma perfeita, a

88 Aurelius Augustinus, Confessionum, XIII, 9, 10; tr. por., p. 334 35. Inclui não só a citação, mas também a argumentação do final do parágrafo.

89 Cfr. Aurelius Augustinus, In epistolam Ioannis ad Parthos Tractatus decem, VIII, 5.

90 Cfr. Aurelius Augustinus, In Evangelium Ioannis Tractatus Centum Viginti Quatuor, 84, 1.

91 Cfr. Aurelius Augustinus, In epistolam Ioannis ad Parthos Tractatus decem, VIII, 4.

92 Cfr. Aurelius Augustinus, In epistolam Ioannis ad Parthos Tractatus decem, I, 1-3.

93 Cfr. Aurelius Augustinus, De diversis quaestionibus octoginta tribus; $36,1$.

94 Cfr. Aurelius Augustinus, De diversis quaestionibus octoginta tribus; 35,2 . O conhecimento e a posse do eterno no amor é a vita beata. Contudo, este conhecimento faz eterna a alma que conhece este “objeto" amado, pois na caridade o homem poderá contemplar 
caridade é o amor entre homem e Deus, mas de um modo que o primeiro ame a Deus propter seipsum e, assim, sobre todas as demais coisas; e essas, o outro e a si mesmo em ordem dele, pois, por exemplo, o amor ao próximo só tem sentido se na mesma orientação do autêntico amor por si mesmo: ter o próprio ser na totalidade de suas dimensões ontológicas (corpo, anima e mens) remetido para a fruição permanente do viver humano, desde o presente, por meio da aderência à vida eterna ${ }^{95}$. Neste sentido pleno, a caritas é uma dilectio. Assim, em síntese, a caridade é a dilectio que intenciona a criatura humana para a realização do seu modo de ser segundo os fins mais próprios ${ }^{96}$, destinando-os a partir da liberdade do espirito, de um ofertar-se a partir de si que não pergunta o porquê nem o para quê. Por isto, ao final, é a caritas a expressão da inversão como experiência do homem, na sua condição de criatura, a retonar àquilo que é, desde a origem, de tal modo que no dinamismo deste amor se encontra os traços essenciais da estrutura vivencial da existência cristã. Todavia, não seria se também se sua fonte e sua forma mais perfeita não fosse admitida como sendo o ser do Criador, isto é, caritas é, em primeiríssimo sentido, a essência da pessoa divina.

\section{Palavras finais: a finitude nas tramas do amor.}

Nas entrelinhas do que se afirmou previamente, apreende-se que a finitude humana se encontra enredada nas tramas do amor. Com efeito, o amor tece uma intricada teia de referências e comportamentos do homem para as coisas e o divino, que se trança, diria Scheler, segundo a ordem de valores vitais. De imediato, esta trama traduz, mediante determinada concreção histórico-singular, o modo como o homem compreende o sentido de ser finito e, assim, orienta a realização de sua mundanidade junto às coisas transitórias. Conforme a compreensão cristã, porém, o homem é passageiro no mundo - "Não sois do mundo" (Jo 15, 19), é a palavra que Cristo dirige a seus discípulos no Evangelho de João -, certamente porque o projeto da existência cristã, o qual se abre e se lança com esta compreensão, é o itinerário da vida humana, movido pelo amor, posta a caminho para o eterno. Ora, a vida humana é uma espécie de navigationen ad patriam, certa viagem para o lugar de origem do homem, cujos passos se fazem não por meio de uma mudança territorial ou deslocamento geográfico, mas de afeto em afeto ${ }^{97}$, ao se retrorreferir (à pertinência) ao Criador. Se o homem é este viator para o eterno, isto não significa que, ele se desprenda por completo das coisas que mudam nem se exime de uma (reta) atinência para com a própria finitude, mas sim, justamente em virtude daquela teia, prende-as consigo,

e fruir de Deus perfeitamente, para sempre, além de sua morte - o que na sua vida presente é possível, ao modo de uma visão limitada, apenas como antecipação e recordação de sua origem. Por causa desta remissão retrospectiva da finitude da vida humana para o eterno como projeto de reestabelecimento de sua plena possibilidade de ser e de plena visão da condição de criatura face a Deus, em consequência, a vita beata não é mais que a vita aeterna.

95 Cfr. Aurelius Augustinus, De doctrina christiana, I, 22, 21; tr. por., p. 59.

96 Como denota, por exemplo, a seguinte afirmação: Tunc est quippe optimus homo, cum tota vita sua pergit in incommutabilem vitam et toto affectu inhaeret illi, "o homem é perfeito quando a sua vida é orientada em direção a vida incomutável e se une a ela com todo o seu afeto" (Aurelius Augustinus, De doctrina christiana, I, 22, 21 ; tr. por., p. 59)

97 Cfr. Aurelius Augustinus, De doctrina christiana, I, 10, 10; 17 , 16 ; tr. por., p. 50,56 . atrelando-as no nexo vivencial de suas relações consigo e demais criaturas. Com isto, remete a si mesmo, o outro e tudo mais para a meta de sua via. Deste modo, esta condição de estar em via somente muda o fulcro da atinência para com a transitoriedade do tempo das coisas, bem como do modo de viver a temporalidade finita de sua existência em meio a elas e em conjunto com os seus compatriotas, que estão, por condição e natureza, na mesma via.

É por atentar-se que atinência é sempre modo de ter(-se). E este ter pode se configurar como tentativa de tomar por bens imutáveis o que somente pode ser passageiro e evanescente e, vice-versa, tomar um bem duradouro como se fosse algo comutável. Na raiz deste mal, certamente, reside o tomar-por que é apoderar, assenhorar, em vista de precaver-se daquilo que é inerente a tudo é finito e passageiro: perder-se, extinguir-se, findar-se e, no caso do ser humano, morrer. Há, pois, um querer tomar posse que não é um deixar ser ou existir, muito menos, deixar ir segundo o caráter efêmero próprio a cada modo de existência. Daí, com maestria, adverte Agostinho que o único motivo do temor seria o medo de perder aquilo que se ama, tanto depois de obtido e ter tomado posse, como também quando ainda o não possui, mas deseja ardentemente tê- $10^{98}$. Todo temor, enquanto ter medo, porém, é guardar-se daquilo que se teme. Deste modo, o homem também teme por não temer que as coisas lhe fujam, na medida em que o homem, frequentemente, deseja se livrar do medo de perder. Todavia, alerta Agostinho, que o temor por não ter o temor de perder coloca a vida humana numa situação ainda mais absurda, pois a fuga daquilo que se teme, enquanto precaver-se de qualquer mal futuro ou eminente, faz abraçar ainda mais aquilo do que se foge. Em todo caso, também nesta situação paradoxal em que a fuga é encontro com o temerário, o homem tenta, por buscar a incessantemente a vita beata, livrar-se constantemente do medo, pois a felicidade, no seu sentido pleno, pressupõe a ausência de medos e a serenidade do ânimo ${ }^{99}$.

De qualquer modo, tanto no temor por perder quanto no temer a ter o medo de um dia vir a perder algo, revela-se que na base destas variações do temor está a submissão dos afetos e do amar humanos aos imperativos do amor concupiscente ${ }^{100}$. Essencialmente, a maior errância do homem neste amor constitui em fazer sua pátria neste mundo passageiro. De que modo? Tomando posse do mundo neste desejo que leva ao domínio por temor de perder. E como se constitui este tomar posse que assenhora? Na medida em que o viver humano confunde que o gozo somente é justo na fruição daquilo que não se subtrai jamais e, como dito, não daquilo cujo modo de ser apenas permite ser para o uso. A prova dada por Agostinho é, em resumo, a seguinte: pode-se possuir algo sem amá-lo, por exemplo, no possuir que, ao tomar para si o possuído, deixa para trás o amor (que era o desejo ardente) com que se ambicionava o que se queria possuir. Ao mesmo tempo, pode-se amar algo sem possuí-lo, por exemplo, a beleza física que alguém gostaria se apresentar ou aquela com a qual o outro se apresenta. Mas nas coisas do espírito, quando não há cisão entre conhecer e amar, a tomada de posse comporta-se de modo diverso, por exemplo, nas

98 Cfr. Aurelius Augustinus, De diversis quaestionibus octoginta tribus; 33. Inclui a argumentação do parágrafo até a próxima referência.

99 Cfr. Aurelius Augustinus, De diversis quaestionibus octoginta tribos, 34 .

100 Cfr. Aurelius Augustinus, De diversis quaestionibus octoginta tribus; 35, 1. 
formas autênticas de aprendizagem (disciplina). Nelas, conhecer é possuir, pois, quanto mais se ama o que se conhece, tanto mais se aprende o "objeto" desta disciplina e, assim, vem a ser melhor e propriamente possuído. Deste modo, bonum quod non amatur nemo potest perfecte habere vel nosse, "não seria possível possuir e conhecer perfeitamente um bem que não se ama". Por isto, o amor não exclui a posse, mas a aperfeiçoa. Qual amor, porém? Certamente, exclusivamente aquele que faz com este tomar posse perca todo aquele caráter de assenhorar e apoderar, particular ao desejo concupiscente e ambicioso. Este amor não é, então, appetitus, mas sim a caritas, que se deve nutrir em função de fazer prevalecer a liberdade sobre a escravidão do temor ${ }^{101}$.

Nesta perspectiva, é sob a caritatis libertas, da constante libertação da concupiscência para liberar o mais próprio de si na justa relação com as coisas, mediante o amor-caridade, que se dá, progressivamente, a conversão das referências do homem para tudo que é imutável ou eterno, convergindo todo seu ser para a pertinência absoluta a Deus. Ao longo da convergência desta conversão, a vida humana, desde as circunstâncias variáveis de sua condição finita e viandante no mundo, é remetida para a vita beata $\mathrm{e}$ aeterna - o que implica o tomar posse de todas as coisas e um ater-se a si e ao outros em um modo capaz de permitir que tanto as criaturas sejam segundo o caráter efêmero, conforme a particularidade de cada realidade transitória, bem como seu finir (da vida humana) e findar (das coisas) delas, isto é, que também não sejam. Assim, a passagem gradual para a dependência do eterno toma como graça tanto o ser como o não-ser. Mas como se dá esta passagem, em que é possível ao homem se libertar, passo a passo, do amor-apetite concupiscente que leva inevitavelmente à posse-apoderamento-senhorio ao amor-caridade que liberta para ser e não ser? Ora, pela compreensão da fé cristã, esta passagem é aquela da mortalidade para imortalidade, melhor, da existência humana em corpo corruptível para uma existência em corpo incorruptível ${ }^{102}$. Em outros termos, é passagem do que o homem é na vida sob a terra, de sua condição de passageiro e viandante, para o que ele ainda não é, a saber, plenamente inserido no viver em Deus, habitante na pátria eterna, na fruição plena da beatitude. De outro lado, este estado em que ele ainda não se encontra, este viver que ele ainda não pode viver em razão de sua mortalidade, será possível futuramente, porque ele, no presente, já está destinado segundo sua condição de criatura. Tudo isto, de outro modo, diz que o homem somente pode passar para o que ele não é a partir do que é. Com efeito, o homem passa constantemente para a vida pela morte, bem como é pela experiência, vivida a todo instante, da sua mortalidade que ele passa constantemente para a vida. Por mais óbvio que pareça, é pela mortalidade mesma, por uma autêntica experiência da finitude, que é dado ao homem alcançar a almejada vita beata ${ }^{103}$. E isto de tal modo que aquela experiência da inversão do ordo amoris em direção à condição originária do viver humano enquanto criatura, pensada como conversão, já é o lugar desta experiência profunda da mortalidade: Cuius autem animus non moritur huic saeculo neque incipit configura-

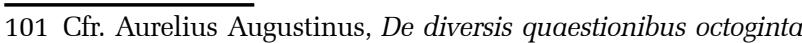
tribus; 35, 2.

102 Cfr. Aurelius Augustinus, De doctrina christiana, I, 19, 18; tr. por., p. 57.

103 Como mostra É. Gilson (Introdução aos estudos de Santo Agostinho, p. 321-26), na compreensão cristã e agostiniana, já na experiência da vida corporal e terrena, o morrer aos interesses e prioridades das ida- ri veritati, in graviorem mortem morte corporis trahitur, "aquele cuja alma não morre para este mundo e não começa a se moldar pela verdade incorrerá numa morte mais grave do corpo." 104 . A liberação operada pela caridade se dá, pois, mediante a morte ao mundo (saeculum), embora seja para amar o universum, respeitando e conservando o lugar ocupado por cada bem na perfeita ordem ou harmonia, predisposta no amor divino, bem como acolhendo que, nele, cada coisa nasce e perece.

Na caritas, então, o homem sabe de si, isto é, compreende o próprio viver como passageiro ou instalado, essencialmente, numa posição intermediária entre o ser o e não-ser, a origem e o nada, enfim, entre o viver e o morrer que o reenvia, novamente, para a origem. Sabe, ao mesmo tempo, das coisas para que o homem tende, estabelecendo um nexo de referências vividas segundo uma ordem dos fins a partir da ciência da própria finitude e do caráter efêmero das coisas. Não nega a efemeridade das coisas que compõe o mundo, como também não foge da morte, pois, é mediante a mortalidade que se torna desperto e atento para a própria origem e destino último. Contudo, de que o homem toma posse na caridade nessa condição passageira e intermediária? Da origem mesma. Sendo este o "objeto" da posse propiciado pela morte, o grande perigo do amor concupiscente consiste em, ao promover a posse do efêmero e não da origem, afastar-se definitivamente do Criador e permanecer para sempre no nada absoluto. E isto também mediante a morte, que não que não se constitui como arremate da experiência de morrer ao século, de perda em vida, mas sim da fuga da própria mortalidade e tentativa de eternizar-se nele. A morte é forte, pois pode fazer o homem perecer no eterno. Quão forte, porém, é o

des precedentes é necessário para, na maturidade, alcançar a tranquilidade e um modo de vida mais feliz. O homem não chega, por exemplo, à nobreza da maturidade da vida adulta, caracterizada pelo elã pela vida justa e social, se não tiver morrido, bem antes, ao impulso de ocupar-se totalmente com a vida do corpo, desvelo e ocupação específicos da tenra idade. De idade em idade, nesta mortalidade em vida corporal, até morrer definitivamente, o homem pode realizar com ordem e beleza seu modo de ser. No entanto, é na experiência da vida no espírito, que a mortalidade é exigida como caminho incontornável de uma passagem que se dá, paradoxalmente, ao modo de um nascimento, pois esta se configura como a experiência contínua transformação do homem exterior e velho no homem novo ou interior, conduzindo-o à progressiva perfeição de seu ser. Nisto, revela-se que o homem interior possui seu específico desenvolvimento espiritual com idades próprias, até atingir aquela idade eterna em que se supera por completo o apego às coisas terrestres e até a morte corporal. Na medida em que a morte do homem velho para o homem novo acontece ao longo do viver finito do homem como sua busca constante e luta diária para nascer no espírito, tal experiência antecede a morte corporal, mas também a inclui como um lugar ou um conduto de passagem para a plenitude da vida espiritual.

104 Cfr. Aurelius Augustinus, De doctrina christiana, I, 20, 19; tr. por., p. 57. Note-se que o mundo (mundus) não possui mais o caráter de totalidade do criado, terra e céus, enquanto perfeição da obra divina, sim possui a acepção de saeculo. Neste sentido, o mundo não é mais o universum, a totalidade ordenada constituída pelo ens creatum, mas aquele "mundo" que nasce com o amor dos dilectores mundi, ao fazer do criado sua casa e sua pátria (cfr. M. Heidegger, Vom Wesen des Grundes, in Wegmarken, Frankfurt a. M.: Vittorio Klostermann, 2004, p. 144-45; tr. por., A essência do fundamento, in Marcas do caminho, Petrópolis: Vozes, 156-58. Neste sentido, "século exprime justamente a temporalização do mundo, não o mundo em relação ao qual a criatura está depois, mas o mundo que ela própria constitui pelo seu ser do mundo (...). O termo século (saeculum) quer dizer o fim do gênero humano (genus humanum)" H. Arednt, O conceito de amor em Santo Agostinho, p. 83. 
amor capaz de reenviá-lo retrospectivamente para a origem e viver plenamente. Todavia, no poder deste amor está também a capacidade de fazer o homem bem morrer, de permitir a ele deixar a morte seja morte, enquanto vive e já na condição de peregrino à pátria eterna. É ambígua, pois, a referência do homem para o morrer, como também para o viver. Para o homem ser na origem desde o presente, assim como tomar posse definitiva da origem no futuro, a morte deve ser a experiência do viver mesmo, isto é, uma certeza constante do próprio viver e o conduto da passagem contínua do habitar o mundo pelo desejo para o habitar em Deus na caridade. Do mesmo modo, para o mesmo fim, o viver deve ser o saber certo que resulta da experiência do morrer mesmo, a cada instante e no fim último da existência. Por isto, na caridade, no homem não nasce e depois morre, nem morre e depois nasce para o eterno. Ele nasce $e$ morre, em todo instante. O enigma da conjunção "e" é o mistério do existir como ens amans.

Não obstante a equivalência operada pela compreensão cristã entre vita beata e vita aeterna, o que aqui se ressalta não é o problema se são suficientes ou não as razões para admitir a sobrevivência da vida após a morte. Não se trata de uma questão de demonstração da imortalidade da pessoa humana ou de uma refutação da crença na sobrevivência da vida em base da alegação de uma ilusão tipicamente humana construída a partir de mecanismos psicológicos ou até histórico-culturais. Para este debate, poder-se-ia apelar para Scheler e mostrar que, a partir do sentido e da essência da ideia de sobrevivência e dos atos de experiência pelos quais a pessoa humana se dá para si mesma já enquanto vive ${ }^{105}$, faltam fundamentos tanto para afirmar se a pessoa existe e como existe após a morte, bem como para refutar a continuidade de sua existência ${ }^{106}$. E isto, grosso modo, em base do dado fenomenológico: à autoexperiência da pessoa pertence, conforme às leis de sua essência, um ato dinâmico e fundamental de "lançar-se para diante, execeder", presente ao longo da "vivência completa e o ser total da pessoa" (também no ato de morrer a própria morte), o que implica o conteúdo experiencial a respeito de si de uma constante "independência de seu ser relativamente ao corpo". Eximindo-se da demonstração fenomenológica desde dado fundamental de como se mostra o viver e o morrer da pessoa humana, importa, antes, evidenciar que o amor impõe uma nova experiência sobre a morte,

105 Cfr. M. Scheler, Tod und Forteleben, p. 38; tr. por.; p. 50. Note-se que Scheler distuinge a questão da eternidade do espírito da ideia da (crença na) sobrevivência da pessoa, discutindo na obra citada somente a segunda questão. A sua discussão, com efeito, visa a demonstração de atos eidéticos que determinam o sentido do viver humano, não uma esfera de signifcações eternas e intemporais, determinando ideias e objetos que são reltivos à vida humana, porém, somente de modo contigencial. A discussão da questão nesta última perspectiva pode levar à aceitação de uma realidade divina e, no máximo, da relação humana com a divindidade. Na perspectiva da sobrevivência da pessoa, porém, está em questão o sentido da morte a partir da experiência permanente do viver mesmo e, daí, a aceitação da ideia da sobrevivência oriunda de uma siginifação dada pela essência da pessoa humana e atos pelos quais ela manifesta a si mesma e para si mesma.

106 Cfr. M. Scheler, Tod und Forteleben, p. 46-47; tr. por.; p. 61-62. Incluem as citações logo a seguir. que não a nega a partir de impulsos vitais, reprimindo a evidência da morte evidência inerente ao viver ou tomando-a como um dado empírico do fim da vida e, no muito, como um fato empírico da vida alheia. É nessa atinência à morte, com efeito, que o homem se agarra somente ao viver mesmo, expressando um modo de vida caracterizado por uma serenidade e tranquilidades totalmente indiferentes à morte ${ }^{107}$. Por certo, esta expulsão cotidiana da evidência superluminosa da morte do seio do viver está intimamente relacionada, numa perspectiva de favorecimento de ações úteis e proveitosas, com a seriedade, peso e significado que o homem se entrega diariamente às preocupações diárias, afazeres e ocupações habituais, trabalhos. Sob a "ameaça" e o constante pensamento na morte, pois, o homem não poderia manter-se ativo e produtivo nas tarefas relacionadas com a preservação e manutenção da vida. De outro lado, porém, desvia-se de sua condição mortal, caracterizando, nos termos de Scheler, certa "leviandade metafísica", condição cotidiana do viver humano, produzido por seus próprios impulsos, mas que também poderia ser pensada tendo os olhos nos perigos, conforme o alerta do pensamento agostiniano, presentes no modo do homem ser passageiro e de tomar posse da própria finitude e das coisas efêmeras, movido pelo desejo concupiscente. Na mesma direção, é preciso recordar igualmente do alerta de Scheler, já com os olhos na condição humana a que humanidade foi encaminhada pelos princípios e decisões da modernidade europeia, que o modo de viver do homem moderno está totalmente dominado por impulsos que fazem a não ser mais que o cálculo da vida, de sua potenciação a fins utilitaristas do trabalho e da produção, do lucro e progresso ilimitados, assim como da sua proteção contra qualquer ideia da morte, eliminando-a por completo. "Mas a inexistência da morte é, efetivamente uma forma de ilusão negativa, própria da consciência do moderno tipo de homem. A morte já não é mais temida por si mesma, porque sua ideia é posta de lado, é afastada pela mesma angústia vital que leva a submeter ao cálculo no decurso da vida" ${ }^{108}$.

Em direção oposta, o amor que pertence ao viver propriamente humano faz atentar para a morte e permite tomá-la como condição de possibilidade de viver. Então, deve-se questionar como e até que ponto tal amor pode superar as "forças que reprimem a ideia de morte mais do que o impulso vital exige" ${ }^{109}$. Não obstante, também isto seja a condição para a admissão da sobrevivência da pessoa, de sua remissão para o eterno, sobretudo, sob o ponto de vista da compreensão que estrutura a vivência cristã, nas linhas acima, apenas indicou-se que sob a questão do amor está a interrogação sobre o sentido do viver e do morrer, ao lado da pergunta da possibilidade de recuperar a cadência própria ao viver e de orientá-lo para a sua essência. Com efeito, na medida em que o amor enreda também a morte nas suas tramas e não só as coisas e pessoas que ama, desvia ou envia para a justa compreensão da finitu-

107 Cfr. M. Scheler, Tod und Forteleben, p. 27-28; tr. por.; p. 34-35. 108 Cfr. M. Scheler, Tod und Forteleben, p. 30; tr. por.; p. 38. 109 Cfr. M. Scheler, Tod und Forteleben, p. 36; tr. por.; p. 47. 
de humana e para relação adequada com a efemeridade das coisas com que o viver inevitavelmente lida. Para uma discussão mais ampla e penetrante desta questão, é preciso que a morte seja pensada a partir da experiência da vida e, vice-versa, visualizar com clarividência que a ideia e imagem própria da vida humana não pode ser retirada a não ser de uma genuína experiência e compreensão do morrer. Neste sentido, conclui-se como uma observação de Scheler: "a morte pertence à forma e à estrutura na qual, somente, cada vida nos é dada, a nossa tal como a dos outros, e isto tanto do interior como o do exterior" ${ }^{110}$. Recorda-se, também a título conclusivo, que o pensamento de Agostinho hermenêutica do viver cristão, cujo esforço, entre outros, é traduzir em conceitos a evidência da mensagem cristã de que quem não ama permanece na morte ${ }^{111}$. E esta é a condição em que o viver se excede senão no dinamismo do desejo, mas que não ultrapassa os limites de determinada figura perecível do mundo. Assim, nesta condição, é o viver que vive a si no engano de querer eternizar o temporário (por exemplo, multiplicando-o ilimitadamente em vista do lucro, como faz o homem moderno) e na pretensão de aniquilar a mortalidade. Deste modo, por certo, no horizonte deste diálogo, a questão do amor poderá iluminar uma compreensão acerca do viver e do morrer capaz de atingir o núcleo da questão da finitude humana e, consequentemente, dizer algo de essencial como é possível ao homem, nos tempos atuais, reaprender a morrer a própria morte.

\section{REFERÊNCIAS}

AURELIUS AUGUSTINUS. Confessionum libri XII (on line), disponível em www.augustinus.it, acesso em 13/12/2017; tr. por., Confissões. Petrópolis: Vozes, 2002.

. De doctrina christiana libri quatuor (on line), disponível em www.augustinus.it, acesso em 13/12/2017; tr. por., A doutrina cristã: manual de exegese e formação cristã. São Paulo: Paulus, 2002.

. De diversis quaestionibus octoginta tribos (on line), tr. it.; Ottantre questioni diversi (on line), disponível em www.augustinus.it, acesso em 13/12/2017.

. De libero arbitrio libri três (on line), disponível em www.augustinus.it, acesso em 13/12/2017; tr. por., $O$ livre arbítrio. Braga: faculdade de Filosofia, 1986.

. In epistolam Ioannis ad Parthos tractatus decem (on line), tr. it.; Commento alla lettera di San Giovanni (on line), disponível em www.augustinus.it, acesso em 13/12/2017.

. In evangelium ioannis tractatus centum viginti quatuor (on line), tr. it.; Commento al vangelo di San Giovanni (on line), disponível em www.augustinus.it, acesso em $13 / 12 / 2017$.

ARENDT, H. O conceito de amor em Santo Agostinho. Lisboa: Piaget, 1997.

110 Cfr. M. Scheler, Tod und Forteleben, p. 22; tr. por.; p. 28.

111 Cfr. AURELIUS AUGUSTINUS, In epistolam Ioannis ad Parthos Tractatus decem, V, 10.
ARISTÓTELES. Metafísica. São Paulo: Loyola, 2002.

BONAVENTURA. Itinerario della mente in Dio. Arezzo: La Verna, 1987; tr. por., SÃO BOAVENTURA. Itinerário da mente para Deus. Petrópolis: Vozes, 2012.

DESCARTES, R. Discours de la méthode. Paris: GF Flammarion, s.d.

GILSON, É. La filosofia di San Bonaventura. Milano: Jaca Book, 1994.

Introdução ao estudo de Santo Agostinho. São Paulo: Discurso editorial; Paulus, 2006.

HEIDEGGER, M. Besinnung. Frankfurt a. M.: Vittorio Klostermann, 1997; tr. por., Meditação. Petrópolis: Vozes, 2010.

. Der eurpäische Nihilismus. In: . Nietzsche II. Stuttgart: Günhter Neske, 1998.

p. 23-229; tr. por., O niilismo europeu. In: HEIDEGGER, M. Nietzsche II. Rio de Janeiro: Forense Universitária, 2007. p. 21-193.

Phänomenologie und Theologie. In: Wegmarken. Frankfurt a. M.: Vittorio Klostermann, 2004. p. 35-77; tr. por., A essência do fundamento. In: HEIDEGGER, M. Marcas do caminho. Petrópolis: Vozes: 2008. p. 56-88.

Vom Wesen des Grundes. In: Wegmarken Frankfurt a. M.: Vittorio Klostermann, 2004. p. 123175; tr. por., A essência do fundamento. In: HEIDEGGER, M Marcas do caminho. Petrópolis: Vozes: 2008. p. 134-188.

Der Satz vom Grund. Stuttgart: Kett-Cotta, 2006; tr. por., O princípio do fundamento. Lisboa: Piaget, 1999.

. Agustinus und der Neuplatonismus. In: . Phänomenologie des religiösen Lebens. Frankfurt a. M.: Vittorio Klostermann, 2011. p. 156-299; tr. por., Agostinho e o neoplatonismo. In: HEIDEGGER, M. Fenomenologia da vida religiosa. Petrópolis: Vozes, 2010. p.141-288.

HUSSERL, E. Ideen zu einer reinen Phänomenologie und phänomenologischen Philosophie. Hamburg: Meiner, 2009; tr. por., Ideias para uma fenomenologia pura e para uma filosofia fenomenológica. Aparecida: Ideias \& Letras: 2006.

RAMOS, D. R. Amor e conhecimento na fenomenologia de Max Scheler. In: Aoristo: International Journal of Phenomenology, Hermeneutics and Metaphysics, 1 (2017), v. 2, Toledo, p. 144-7.

ROMBACH, R. Strukturanthropologie. »Der menschliche Mensch«. Freiburg/München: Karl Alber, 1993; tr. esp., Antropología estrutural. El hombre humanizado. Barcelona: Herder, 2004.

SCHELER, M. Der Formalismus in der Ethik und die materiale Wertethik. GW 2. Bonn: Bouvier, 2000; tr. it. Il formalismo nell'etica e l'etica materiale dei valori. Milano: San Paolo, 1996. 
Das Ressentiment im Aufbau der Moralen. In: Vom Umsturz der Werte. Abhandlungen und Aufsätze. GW 3. Bonn: Bouvier, 2007. p. 33-147; tr. por. O ressentimento na construção das morais. In: SCHELER, M. Reviravolta dos valores. Petrópolis: Vozes, Bragança Paulista: São Francisco, 2012. p. 43-182.

. Vom Ewigen im Menschen. GW 5. Bonn: Bouvier, 2007; tr. por. Do eterno no homem. Petrópolis: Vozes, Bragança Paulista: São Francisco: 2015.

. Vom Wesen der Philosophie und der moralischen Bedigung des philosophischen Erkennens. In: SCHELER, M. Vom Ewigen im Menschen. GW 5. Bonn: Bouvier, 2007. p. 61-99; tr. por. Sobre a essência da filosofia e a condição moral do conhecimento. In: SCHELER, M. Do eterno no homem. Petrópolis: Vozes, Bragança Paulista: São Francisco: 2015. p. 81-132.

. Liebe und Erkenntnis. In: SCHELER, M. Schriften zur Soziologie und Weltanschauungslehre. GW 6. Bonn: Bouvier, 2005. p. 77-98; tr. esp., Amor y conocimento. In: SCHELER, M. Amor y conocimento. Madri: Palabra, 2010. p. 11-48.

. Wesen und Formen der Sympathie. GW 7. Bonn: Bouvier, 2005. p. 7-258; tr. esp.; Esencia y formas de la simpatia. Buenos Aires: Losada, 1943.

. Die Stellung des Menschen im Kosmos. In: SCHELER, M. Späte Schriften. GW 9. Bonn: Bouvier, 2008. p. 7-71; tr. por. A posição do homem no cosmos. Rio de Janeiro: Forense Universitária, 2003.

. Tod und Fortleben. In: SCHELER, M. Schriften aus dem Nachlaß. Zur Ethik und Erkenntnislehre. GW 10, Band I. Bonn: Bouvier, 2000. p. 9-64. tr. por. Morte e sobrevivência. Lisboa: Edições 70, 2017.

. Ordo Amoris. In: Schriften aus dem Nachla $\square$. Zur Ethik und Erkenntnislehre. GW 10, Band I. Bonn: Bouvier, 2000. p. 345-76. tr. por. Ordo amoris (on line), p. 24-25. Diponível em: <http.www.lusosofia.net>. Acesso em: 26 jul. 2016.

Daniel Rodrigues Ramos é Professor Adjunto no curso de Filosofia da Universidade Federal do Recôncavo da Bahia (UFRB). Email: dr.ramos@ufrb.edu.br

Recebido em 23.01.2018

Aceito em 12.09.2018 